\title{
How Far Can One Push the Noble Gases Towards Bonding?: A Personal Account
}

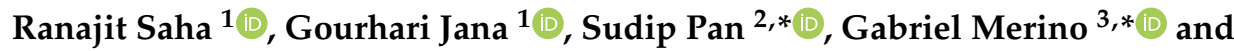 \\ Pratim Kumar Chattaraj $1,4, *$ (i)
}

1 Department of Chemistry and Centre for Theoretical Studies Indian Institute of Technology Kharagpur, Kharagpur 721302, India

2 Institute of Advanced Synthesis, School of Chemistry and Molecular Engineering, Jiangsu National Synergetic Innovation Center for Advanced Materials, Nanjing Tech University, Nanjing 211816, China

3 Departamento de Física Aplicada, Centro de Investigación y de Estudios Avanzados, Unidad Mérida. Km 6 Antigua Carretera a Progreso. Apdo. Postal 73, Cordemex, Mérida 97310, Yuc., Mexico

4 Department of Chemistry, Indian Institute of Technology Bombay, Mumbai 400076, India

* Correspondence: ias_sudippan@njtech.edu.cn (S.P.); gmerino@cinvestav.mx (G.M.); pkc@chem.iitkgp.ac.in (P.K.C.)

Received: 13 July 2019; Accepted: 30 July 2019; Published: 13 August 2019

\begin{abstract}
Noble gases (Ngs) are the least reactive elements in the periodic table towards chemical bond formation when compared with other elements because of their completely filled valence electronic configuration. Very often, extreme conditions like low temperatures, high pressures and very reactive reagents are required for them to form meaningful chemical bonds with other elements. In this personal account, we summarize our works to date on $\mathrm{Ng}$ complexes where we attempted to theoretically predict viable $\mathrm{Ng}$ complexes having strong bonding to synthesize them under close to ambient conditions. Our works cover three different types of $\mathrm{Ng}$ complexes, viz., non-insertion of $\mathrm{NgXY}$ type, insertion of $\mathrm{XNgY}$ type and $\mathrm{Ng}$ encapsulated cage complexes where $\mathrm{X}$ and $\mathrm{Y}$ can represent any atom or group of atoms. While the first category of $\mathrm{Ng}$ complexes can be thermochemically stable at a certain temperature depending on the strength of the $\mathrm{Ng}-\mathrm{X}$ bond, the latter two categories are kinetically stable, and therefore, their viability and the corresponding conditions depend on the size of the activation barrier associated with the release of $\mathrm{Ng}$ atom(s). Our major focus was devoted to understand the bonding situation in these complexes by employing the available state-of-the-art theoretic tools like natural bond orbital, electron density, and energy decomposition analyses in combination with the natural orbital for chemical valence theory. Intriguingly, these three types of complexes represent three different types of bonding scenarios. In $\mathrm{NgXY}$, the strength of the donor-acceptor $\mathrm{Ng} \rightarrow \mathrm{XY}$ interaction depends on the polarizing power of binding the $\mathrm{X}$ center to draw the rather rigid electron density of $\mathrm{Ng}$ towards itself, and sometimes involvement of such orbitals becomes large enough, particularly for heavier $\mathrm{Ng}$ elements, to consider them as covalent bonds. On the other hand, in most of the $\mathrm{XNgY}$ cases, $\mathrm{Ng}$ forms an electron-shared covalent bond with $\mathrm{X}$ while interacting electrostatically with $\mathrm{Y}$ representing itself as $[\mathrm{XNg}]^{+} \mathrm{Y}^{-}$. Nevertheless, in some of the rare cases like $\mathrm{NCNgNSi}$, both the $\mathrm{C}-\mathrm{Ng}$ and $\mathrm{Ng}-\mathrm{N}$ bonds can be represented as electron-shared covalent bonds. On the other hand, a cage host is an excellent moiety to examine the limits that can be pushed to attain bonding between two $\mathrm{Ng}$ atoms (even for $\mathrm{He}$ ) at high pressure. The confinement effect by a small cage-like $\mathrm{B}_{12} \mathrm{~N}_{12}$ can even induce some covalent interaction within two He atoms in the $\mathrm{He}_{2} @ \mathrm{~B}_{12} \mathrm{~N}_{12}$ complex.
\end{abstract}

Keywords: noble gas; electron density; bonding; electron localization function; energy decomposition analysis 


\section{Introduction}

Helium (He) and argon (Ar) are the first noble gas $(\mathrm{Ng})$ elements that found a place in the Mendeleev's periodic table as group ' 0 ' members [1]. The modern version of the periodic table has a total of seven $\mathrm{Ng}$ elements, viz., helium $(\mathrm{He})$, neon (Ne), argon (Ar), krypton ( $\mathrm{Kr})$, xenon (Xe), radon $(\mathrm{Rn})$ and oganesson $(\mathrm{Og})$ and they are positioned in group 18. Among them, the last two elements are radioactive in nature. Og was only recently discovered in 2006 and its chemical and physical properties have yet to be studied in a broad sense. Very recently, because of the tremendous relativistic effect, Og was reported to possess semiconductor properties in the solid-state [2]. The main electronic characteristic of $\mathrm{Ng}$ atoms is their filled valence $n s^{2}$ and $n p^{6}$ orbitals (for He only $n s^{2}$ ). In principle, these electronic configurations hinder these elements from getting chemically involved with other elements, which results in the isolation of Ngs in terms of reactivity and accordingly the chemistry world terms them as "inert gases". In this group, the first ionization potentials (IP) follow a descending order along the bottom of the group (see Figure 1) [3]. If we look at these IP values, it is obvious that they possess high enough IPs to support their inertness, but another observation is that the IPs decrease monotonically from He to Rn. Thus, it is possible to knock out an electron from the outermost shell of the heavier Ngs and $\mathrm{Ng}$-compounds thus become viable. Kossel predicted that $\mathrm{Kr}$ and $\mathrm{Xe}$ should be able to form the corresponding fluorides [4]. In 1924, Antropoff claimed that Ng atoms can expand their valence up to eight and should therefore be placed in Group VIIB [5]. In his words, "one should not forget that as the valence number increases from one group to the next, the intensity of the valence forces decreases" [6]. Pauling, based on ionic radii, predicted that Xe can coordinate with oxygen and form xenic acid $\left(\mathrm{H}_{4} \mathrm{XeO}_{6}\right)$, which "should form salts such as $\mathrm{Ag}_{4} \mathrm{XeO}_{6}$ and $\mathrm{AgH}_{3} \mathrm{XeO}_{6}$ " [7]. The radius ratio $\mathrm{O}^{2-}$ and $\mathrm{F}^{-}$is 1.29 , and this observation led Pauling to further predict the existence of krypton hexafluoride $\left(\mathrm{KrF}_{6}\right)$, xenon hexafluoride $\left(\mathrm{XeF}_{6}\right)$, and xenon octafluoride $\left(\mathrm{XeF}_{8}\right)$. However, several attempts to synthesize $\mathrm{Ng}$ compounds failed until 1962. One notable mention is the electric discharge experiments to synthesize $\mathrm{XeF}_{6}$ or $\mathrm{XeF}_{8}$ by Yost and Koye. It is reported that they had tried the experiments 20 times in a week, but all the experiments failed.

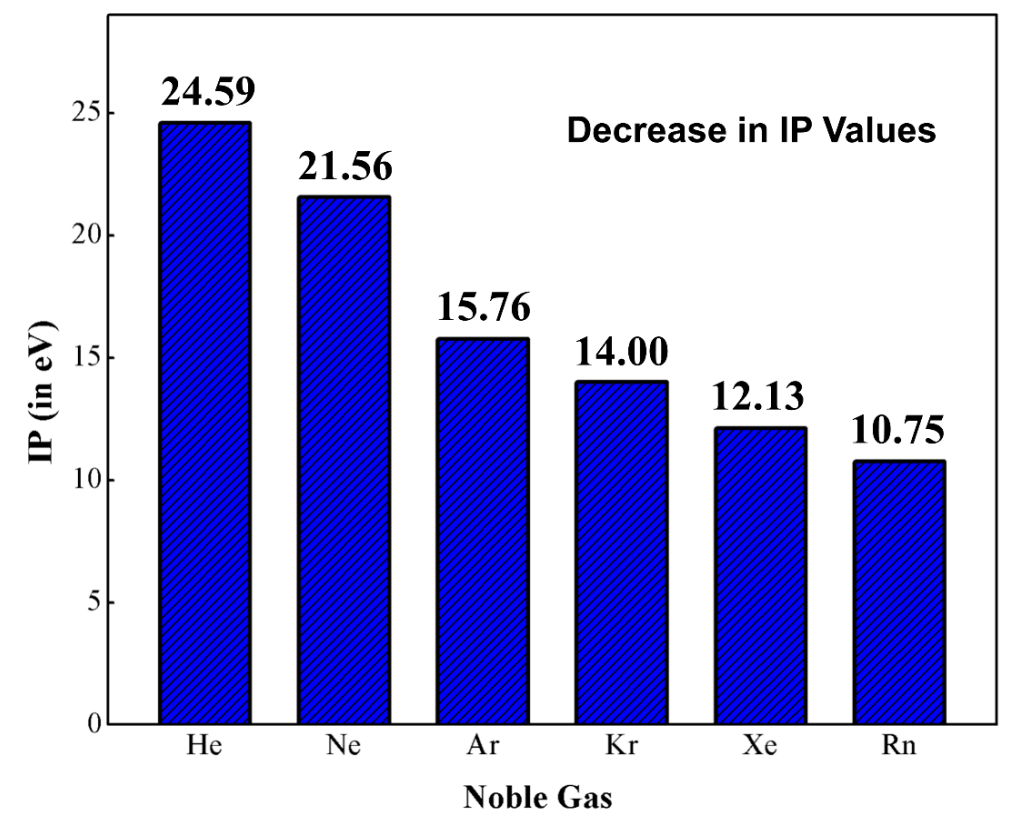

Figure 1. The plot of first ionization potential (IP; eV) against noble gas elements.

The long period of inertness of Ngs came to an end with the works of Bartlett in 1962. Bartlett accidentally synthesized the complex $\mathrm{O}_{2}{ }^{+} \mathrm{PtF}_{6}{ }^{-}$, which is red in color and was unexpected as per his reaction schemes [8]. The extremely high oxidizing power of $\mathrm{PtF}_{6}$ was able to oxidize $\mathrm{O}_{2}$. The IP for $\mathrm{O}_{2}$ to $\mathrm{O}_{2}{ }^{+}$is very high $(12.07 \mathrm{eV})$, which is almost equal to that of $\mathrm{Xe}$ to $\mathrm{Xe}^{+}(12.13 \mathrm{eV})$. Based on these 
similar IP values, he idealized a similar experimental procedure to make a complex between Xe and $\mathrm{PtF}_{6}$ and the result was positive [9]. In his own words, "When I broke the seal between the red PtF gas and the colorless xenon gas, there was an immediate interaction, causing an orange-yellow solid to precipitate" [10]. This ground-breaking discovery broke the century-long myth and opened a completely new field known as "Noble Gas Chemistry". Initially, the formula of the first $\mathrm{Ng}$ compound was thought to be $\mathrm{Xe}^{+} \mathrm{PtF}_{6}{ }^{-}$, but $\mathrm{X}$-ray powder diffraction photographs (XRDP) revealed the existence of $\mathrm{XeF}^{+} \mathrm{Pt}_{2} \mathrm{~F}_{11}{ }^{-}$ but no $\mathrm{Xe}^{+} \mathrm{PtF}_{6}{ }^{-}$in the solid form [11]. The mechanism of formation of $\mathrm{XeF}^{+} \mathrm{Pt}_{2} \mathrm{~F}_{11}{ }^{-}$was established via quantum-chemical computations by Christe $[12,13]$. The reaction is catalyzed by $\mathrm{F}^{-}$ion and it explains the presence of $\mathrm{XeF}^{+} \mathrm{PtF}_{6}{ }^{-}, \mathrm{PtF}_{5}$, and $\mathrm{XeF}^{+} \mathrm{Pt}_{2} \mathrm{~F}_{11}{ }^{-}$.

Though Bartlett failed to give an accurate structure for the yellow solid at the time, his work opened a new branch of chemistry. The notion that Ng elements "Do not make bond(s)" was disproven and within a year several $\mathrm{Ng}$ compounds, viz., $\mathrm{XeF}_{2}, \mathrm{XeF}_{4}, \mathrm{XeF}_{6}, \mathrm{XeOF}_{4}, \mathrm{XeO}_{3}$, and $\mathrm{KrF}_{2}$ were synthesized and characterized [14,15]. Xe was the most studied element among the group 18 elements due to its loosely bonded electrons and numerous reports appeared in the literature about species like $\mathrm{XeF}_{2}$, $\mathrm{XeF}_{4}, \mathrm{XeF}_{6}, \mathrm{XeOF}_{4}, \mathrm{XeO}_{3}$, and many more [16-21]. Even radioactive $\mathrm{Rn}$ was successfully employed to make compounds, $\mathrm{RnF}_{2}$ and [RnF] $\left[\mathrm{Sb}_{2} \mathrm{~F}_{11}\right]$ being two examples among them [22]. In 2000, the group of Räsänen successfully isolated the first Ar compound, HArF, in a low-temperature matrix [23,24]. Several weak Ne complexes, namely $\mathrm{NeAuF}, \mathrm{NeBeS}, \mathrm{NeBeCO}_{3}, \mathrm{NeBeSO}_{2},(\mathrm{Ne})_{2} \mathrm{Be}_{2} \mathrm{O}_{2},\left(\mathrm{NeAr} \mathrm{Be}_{2} \mathrm{O}_{2}\right.$, and $(\mathrm{NeKr}) \mathrm{Be}_{2} \mathrm{O}_{2}$, were also experimentally identified in a low-temperature matrix [25-28]. It should be noted that before Bartlett's discovery, in 1925, Hogness and Lunn observed the presence of the transient species $\mathrm{HeH}^{+}$by bombarding a hydrogen-helium mixture at low pressure [29].

Very recently, Dong et al. showed that at high pressure even He can participate in chemical bonding [30]. They reported a solid $\mathrm{Na}_{2} \mathrm{He}$ compound with a fluorite-type structure under high pressures greater than $113 \mathrm{GPa}$. Bonding analysis by the solid-state adaptive natural density partitioning analysis (SSAdNDP) reveals that in the absence of He in the sodium sublattice each $\mathrm{Na}_{8}$ cube only has one electron. Now, in $\mathrm{Na}_{2} \mathrm{He}$ when helium is included in half of those cubes, the electron density from those cubes occupied by helium gets is pushed to the adjacent empty $\mathrm{Na}_{8}$ cube facilitating the formation of eight-centered two-electron $(8 c-2 e)$ bonds therein. High pressure is needed for such electron shifting to be effective. Hence, all the Ng elements are known to show chemical reactivity. For more details, the readers are referred to the excellent reviews and articles on the $\mathrm{Ng}$ compounds [31-55]. In the current account, we mainly summarize our theoretical contributions in the $\mathrm{Ng}$ field. Our work on $\mathrm{Ng}$ compounds can be classified into three main categories, viz., (a) non-insertion of $\mathrm{NgXY}$ type, (b) insertion of XNgY type, and (c) Ng encapsulated cage complexes (see Figure 2).

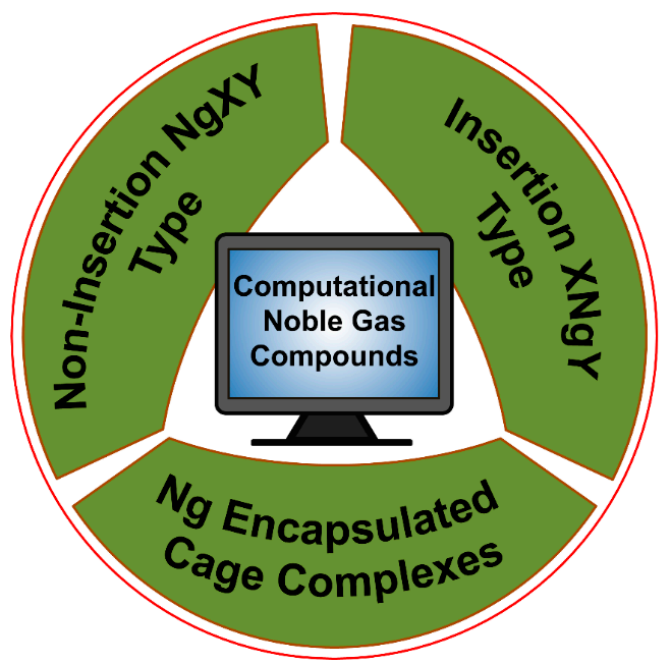

Figure 2. Schematic presentation of the three classes of $\mathrm{Ng}$-compounds discussed in this article. 


\section{Ng Compounds under the Light of Theoretical Chemistry}

Theory complements experiments in developing and restructuring $\mathrm{Ng}$ chemistry. Computational tools are found to be useful in explaining the characteristics of the nature of bonding in $\mathrm{Ng}$ compounds. The computational results can explore that shadowy part and shed light to understand the system more conveniently, but computational chemistry is not restricted to just this application. New sets of molecules, clusters, and complexes of Ngs could be designed and their structures, stability, and nature of their bonding explored using the computational tools.

The computational work starts with the optimization of the designed $\mathrm{Ng}$ compound. At this point, the primary and necessary step is to select a reliable method (ab initio or DFT) that predicts the geometrical, electronic, and energetic parameters with a minimum amount of errors. The ab initio methods like $\operatorname{CCSD}(T)$ along with aug-cc-pVnZ $(n=T, Q, 5)$ or def2-nZVP $(n=T, Q)$ basis sets are the most desirable methods for the calculations regarding the $\mathrm{Ng}$ compounds, but if the systems are large enough, $\operatorname{CCSD}(\mathrm{T})$ level becomes computationally expensive, and then one should go for DFT- based methods. Several benchmark studies have guided the community to find a proper DFT level. The MPW1B95/6-311+G(2df,2pd), BMK/aug-cc-pVTZ, DSD-BLYP/aug-cc-pVTZ, and B2GP-PLYP/ aug-cc-pVTZ levels provide the best accuracy for the bond energies in $\mathrm{Ng}$ compounds, with MUEs of $\sim 2.0 \mathrm{kcal} \cdot \mathrm{mol}^{-1}$ [56]. In contrast, the MP2 method along with aug-cc-pVDZ basis set gave a MUE of $4.5 \mathrm{kcal} \cdot \mathrm{mol}^{-1}$ for these bond energies. In general, the relativistic effects of the Xe and $\mathrm{Rn}$ are taken care of by using either the quasi-relativistic effective core potentials (ECP) or the zeroth-order regular approximation (ZORA). $\mathrm{Ng}$ insertion compounds are more sensitive to the level of theory used. Very often, even if structures turn out to be a minimum at the DFT or MP2 level, at the CCSD(T) level they are shown to become dissociated. Therefore, a high-level CCSD $(\mathrm{T})$ calculation is mandatory to predict new stable Ng-inserted molecules. On the other hand, NgXY-type systems are relatively less sensitive to the level of theory. Only the bond dissociation energy (BDE) changes with the change in the level of theory, but it is very unlikely that a stable species at one level turns out to be unstable at some other level.

The minimum energy geometries are then used to study the nature of bonding of the complexes. Natural bond orbital (NBO) [57], electron density [58], and energy decomposition analyses (EDA) [59,60] are performed. The NBO analysis is very widely used to find out the natural charge distribution of the molecule and to calculate the bond order between any pair of atoms by computing the Wiberg bond index (WBI). The natural charges on each atom help to determine the direction of the charge flow, whereas the WBI values indicate the bond order between two atoms. Electron density analysis helps to assign the nature of bonds based on various electron density-based descriptors. The criterion that the Laplacian of the electron density, $\nabla^{2} \rho\left(r_{c}\right)$, at the bond critical point (BCP) should be negative often fails for $\mathrm{Ng}$ compound cases, which might be because of the relatively weaker orbital involvement in $\mathrm{Ng}$ cases in comparison to the other elements and/or the fact that this criterion very often fails for the heavier elements other than first-row elements. This is because $\nabla^{2} \rho\left(r_{c}\right)$ is derived from the three curvature values $\left(\lambda_{1}, \lambda_{2}\right.$, and $\left.\lambda_{3}\right)$ where $\lambda_{1}$ and $\lambda_{2}$ are negative but the last term is positive. For other than first row elements the latter term very often dominates the former two terms making the resulting $\nabla^{2} \rho\left(r_{c}\right)$ positive. For these cases, the total energy density $H\left(r_{c}\right)$ is a very useful descriptor. Even if $\nabla^{2} \rho\left(r_{c}\right)>0, H\left(r_{c}\right)<0$ signifies covalent bonding or at least partial covalent bonding, depending on the magnitude.

In EDA, the interaction energy $\left(\Delta E_{\text {int }}\right)$ between two fragments is decomposed into four energy terms, viz., the electrostatic interaction energy $\left(\Delta E_{\text {elstat }}\right)$, the Pauli repulsion $\left(\Delta E_{\text {Pauli }}\right)$, the orbital interaction energy $\left(\Delta E_{\mathrm{orb}}\right)$, and the dispersion interaction energy $\left(\Delta E_{\mathrm{disp}}\right)$. Therefore, the interaction energy $\left(\Delta E_{\text {int }}\right)$ between two fragments can be defined as:

$$
\Delta E_{\text {int }}=\Delta E_{\text {elstat }}+\Delta E_{\text {Pauli }}+\Delta E_{\text {orb }}+\Delta E_{\text {disp. }}
$$


$\Delta E_{\text {elstat }}$ is computed classically by taking the two fragments at their optimized positions but considering the charge distribution is unperturbed on each fragment, by another one. The next one is $\Delta E_{\text {Pauli, }}$, which appears as the repulsive energy between electrons of the same spin and it is computed by employing Kohn-Sham determinant on the superimposed fragments to obey the Pauli principle by antisymmetrization and renormalization. $\Delta E_{\text {orb }}$ originates from the mixing of orbitals, charge transfer, and polarization between two fragments. Lastly, $\Delta E_{\text {disp }}$ represents the dispersion interaction between the two fragments. This method is very widely used to analyze the bonding situation in different type of systems [61-71].

\section{Discussion}

\subsection{Non-Insertion Complexes of $\mathrm{NgXY}$ Type}

In this type of $\mathrm{Ng}$ compounds, the $\mathrm{Ng}$ atoms are bound to an open side of a molecule, say $\mathrm{X}$ in an $X Y$ system. The $X$ atom can polarize the electron density from the outermost orbital of the $\mathrm{Ng}$ atom and this produces an attractive interaction between them. The polarizing power of the atom $X$ is responsible for the extent of the interactions between $\mathrm{Ng}$ and $\mathrm{X}$. This interaction can be viewed as a donor-acceptor type of interaction to stabilize the $\mathrm{Ng}-\mathrm{X}$ bond. $\mathrm{Y}$ is the counteranion that stabilizes the whole complex. It is known that $X$ with a small radius and high charge can polarize the $\mathrm{Ng}$ atom more strongly. Due to the difference in electronegativities of $\mathrm{X}$ and $\mathrm{Y}$ a dipole would be created which in turn will polarize the electron cloud of the $\mathrm{Ng}$ atom. Of course, the strength of polarization would be much larger in case it is caused by an ion. For neutral molecules having small electronegativity differences, dispersion would also play a role in bonding.

Prompted by the findings of Pauzat et al. [72-74], one of the first cases that we considered was a triangular $\mathrm{H}_{3}{ }^{+}$cluster interacting with $\mathrm{Ng}$ atoms. Our computations showed that a maximum of three $\mathrm{Ng}$ atoms can form strong bonds with $\mathrm{H}_{3}{ }^{+}$and the strength for the first $\mathrm{H}-\mathrm{Ng}$ bond in $\mathrm{H}_{3}(\mathrm{Ng})^{+}$is significantly stronger than in larger clusters (see Figure 3 for the structures of the systems reported by us) [75]. Further, their stability could be understood in terms of conceptual DFT-based descriptors, where the overall system gets stabilized because of the presence of Ngs, presumably because of the delocalization of the cationic charge. We further compared the $\mathrm{Ng}$ binding ability of $\mathrm{H}_{3}{ }^{+}$with $\mathrm{Li}_{3}{ }^{+}$. Each Li center in a $\mathrm{Li}_{3}{ }^{+}$cluster can also bind with an $\mathrm{Ng}$ atom, resulting in a $\mathrm{Li}_{3}(\mathrm{Ng})_{3}{ }^{+}$cluster but the $\mathrm{Ng}-\mathrm{Li}$ bonds are significantly weaker than the $\mathrm{Ng}-\mathrm{H}$ bonds in the former systems. The $\mathrm{Li}-\mathrm{Ng}$ bond strength in this system is comparable with those of the previously reported $\mathrm{NgLiH}$ and $\mathrm{NgLiF}$ systems. Note that a positive Li center is an automatic choice for hydrogen storage because of its mediocre binding ability lying between physisorption and chemisorption and high gravimetric $\mathrm{wt} \%$ [76-80]. Therefore, it would be interesting to check the relative stability of $\mathrm{H}_{2}$ and $\mathrm{Ng}$ bonded analogues to understand whether a $\mathrm{Ng}$ can replace $\mathrm{H}_{2}$. Also, it is necessary to understand the origin of such an attractive interaction. We have then performed a comprehensive study on the star-shaped $\mathrm{C}_{5} \mathrm{Li}_{7}{ }^{+}$ cluster [81] and $\mathrm{O}_{2} \mathrm{Li}_{5}{ }^{+}$super-alkali cluster [82] as a case study [83,84]. The $\mathrm{C}_{5} \mathrm{Li}_{7}{ }^{+}$cluster can bind up to seven He atoms with the Li centers, whereas for other cases, a maximum of $12 \mathrm{Ngs}(\mathrm{Ne}-\mathrm{Xe})$ can bind. The $\mathrm{O}_{2} \mathrm{Li}_{5}{ }^{+}$cluster is able to bind up to seven $\mathrm{Ng}$ (He-Xe) atoms. A comparison with their interaction with hydrogen molecules reveals that $\mathrm{He}$ and $\mathrm{Ne}$ have slightly lower attractive interactions than $\mathrm{H}_{2}$, whereas for heavier $\mathrm{Ng}$ atoms the interaction is stronger than that with $\mathrm{H}_{2}[78,79]$. We have also considered a series of Li-decorated clusters, viz., $\mathrm{B}_{3}(\mu-\mathrm{Li})_{3} \mathrm{H}_{3}{ }^{+}, \mathrm{B}_{3}(\mu-\mathrm{Li})_{2} \mathrm{H}_{3}, \mathrm{Si}_{5} \mathrm{Li}_{7}{ }^{+}$, $\mathrm{Si}_{4} \mathrm{Li}_{4}, \mathrm{Ge}_{4} \mathrm{Li}_{4},\left[\mathrm{~N}_{4}-\mathrm{B}_{2}-\mathrm{N}_{4}\right] \mathrm{Li}_{2}$ and super-alkali clusters $\left(\mathrm{FLi}_{2}{ }^{+}, \mathrm{OLi}_{3}{ }^{+}, \mathrm{N}_{2} \mathrm{Li}_{7}{ }^{+}\right.$, and $\left.\mathrm{BLi}_{6}{ }^{+}\right)$to justify that such bonding with $\mathrm{Ng}$ is not specific to certain Li-decorated clusters but, in general, a cluster with considerably positively charged Li center can induce a bonding with $\mathrm{Ng}[83,85]$. Moreover, the application of an external electric field improves the Li-Ng bonding. EDA reveals that charge transfer and polarization are the main contributors towards the total attraction, followed by exchange and dispersion interactions. 


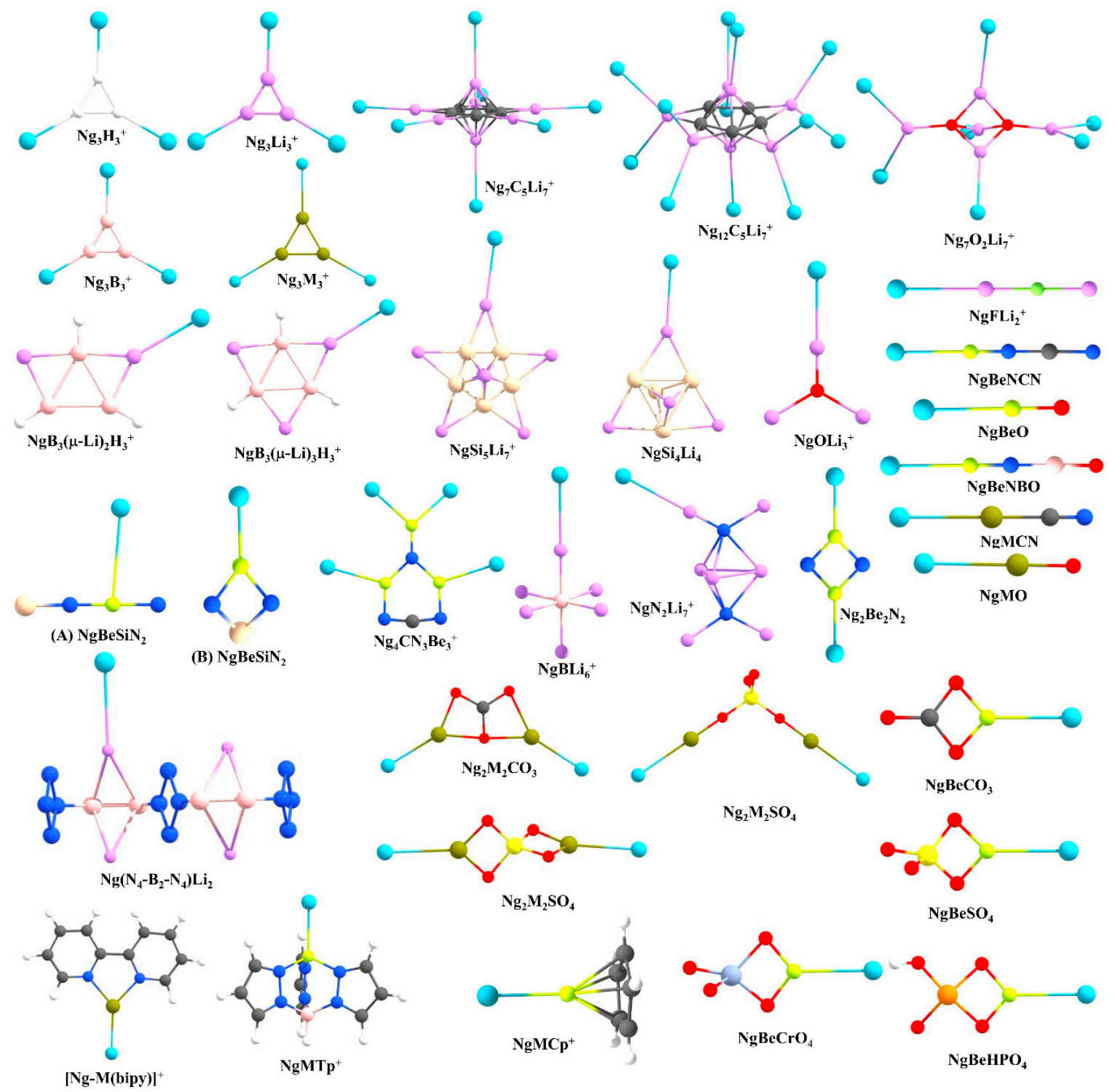

Figure 3. The structures of the NgXY type systems reported by us.

The elements of group 2, mainly beryllium, have shown their potential in this field. Be has significantly larger $\mathrm{Ng}$ binding ability than Li because of its higher ionic potential. In 1988, Frenking and co-workers showed on paper that $\mathrm{BeO}$ can form strong bonds with $\mathrm{Ng}$ atoms in $\mathrm{NgBeO}$ complexes [86]. Later, in 1994, Andrews and co-workers detected ArBeO, $\mathrm{KrBeO}$, and $\mathrm{XeBeO}$ complexes using the pulsed-laser matrix isolation technique [87]. Moreover, the applied charge on $\mathrm{BeO}$ increases the $\mathrm{Ng}$-Be bond strength [88]. These findings motivated us to search for viable $\mathrm{Ng}$-Be complexes. A global minima search for $\mathrm{CN}_{3} \mathrm{Be}_{3}{ }^{+}$molecular formula shows that it has $\mathrm{C}_{2 v}$ symmetry, where two different types of Be centers are present (see Figure 3) [89]. Each Be center connected through the ring can bind only one $\mathrm{Ng}$ atom, but the Be center outside the ring can bind two $\mathrm{Ng}$ atoms, thus making a total of four $\mathrm{Ng}$-atoms bonded to the system. The thermochemical results indicate that the $\mathrm{NgCN}_{3} \mathrm{Be}_{3}{ }^{+}$ cluster might be viable even at ambient temperature, whereas for higher-numbered $\mathrm{Ng}$ bound clusters, the temperature should be lowered. Quite high WBI values reveal that almost half a bond order is attained for $\mathrm{Ng}=\mathrm{Kr}-\mathrm{Rn}$. In the same study, the whole series of $\mathrm{NgBeX}(\mathrm{X}=\mathrm{O}, \mathrm{S}$, Se, Te) and their cationic analogues were also considered. For a given $X$, the cationic species have higher $\mathrm{Ng}$ binding ability than their neutral analogues, whereas for a given $\mathrm{Ng}$, the $\mathrm{Ng}$-Be strength diminishes along $\mathrm{O}$ to Te. In a further study, we searched for the global minimum structures of $\mathrm{Be}_{2} \mathrm{~N}_{2}, \mathrm{Be}_{3} \mathrm{~N}_{2}$, and $\mathrm{BeSiN}_{2}$ 
clusters [90]. Owing to a high positive charge, the Be-center in these clusters can bind to $\mathrm{Ng}$ atoms. $\mathrm{Be}_{2} \mathrm{~N}_{2}, \mathrm{Be}_{3} \mathrm{~N}_{2}$, and $\mathrm{BeSiN}_{2}$ bind a maximum of two, three, and one $\mathrm{Ng}$ atoms through the Be centers, respectively. An interesting finding is that the presence of $\mathrm{Ng}$ atom can alter the energetic sequence of the isomers through their interaction with them. For example, the global minimum structure of BeSiN 2 has a linear shape (A in Figure 3), where Be is located in between two atoms, and therefore, Be is not in a suitable position to interact strongly with $\mathrm{Ng}$ atoms (Figure 3). On the other hand, in the second lowest-lying isomer the Be is in a terminal position with high positive charge and can interact $\mathrm{Ng}$ atoms strongly (B in Figure 3). It was noted that in the presence of Ar-Rn, the second-lowest energy isomer becomes more energetically stable than the linear global minimum isomer. These are important results since many clusters are generated experimentally in a $\mathrm{Ng}$ (Ar) environment!

Various ways to modify the $\mathrm{Ng}$ binding strength of $\mathrm{BeO}$ and $\mathrm{BeNH}$ were investigated thoroughly. For example, the attachment of a Lewis acid like $\mathrm{BH}_{3}$ to the $\mathrm{O}$ atom of $\mathrm{BeO}$ was found to improve the $\mathrm{Ng}$ binding ability as reported by Grandinetti and co-workers. The same authors also noted that the substitution of $\mathrm{H}$ atom in BeNH by different groups makes it a better candidate to bind $\mathrm{Ng}$ atoms [91], but the major drawback of this approach is that the designed systems are not global minima. We found two Be-containing molecules, BeNCN and BeNBO, via substitution of the $\mathrm{H}$ atom of BeNH with CN and $\mathrm{BO}$, respectively, which have a linear global minima structures with Be in a terminal position [92]. These two systems have the highest and the second-highest $\mathrm{Ng}$ binding ability among other reported neutral Be systems. Further, the quest to find suitable Be-based salts that can form strong $\mathrm{Ng}$-Be bonds led to the study of the $\mathrm{Ng}$ binding ability of several $\mathrm{BeX}\left(\mathrm{X}=\mathrm{SO}_{4}, \mathrm{CO}_{3}, \mathrm{HPO}_{4}\right.$, and $\left.\mathrm{CrO}_{4}\right)$ systems [93,94]. The comparative study on the $\mathrm{NgBeSO}_{4}, \mathrm{NgBeCO}_{3}$, and $\mathrm{NgBeO}$ clusters suggests that the $\mathrm{Ng}$-Be bonds are stronger in $\mathrm{NgBeSO}_{4}$ as compared to those in $\mathrm{NgBeCO}_{3}$ and $\mathrm{NgBeO}$ (except for the He-Be case) clusters.

In a further subsequent study, the $\mathrm{Ng}$ binding ability of Be and Mg salts of 1-tris(pyrazolyl)-borate was studied by DFT-based studies [95]. The $\mathrm{Ng}$-Be bonds are stronger than that of the $\mathrm{Ng}-\mathrm{Mg}$ bonds, which is the direct consequence of the small charge to radii ratio in $\mathrm{Mg}$ as compared to that in the Be. In these positively charged complexes, the $\mathrm{M}$ centers polarize the electron density on the $\mathrm{Ng}$ atoms. The EDA in combination with natural orbital for chemical valence (NOCV) also showed that the orbital interactions are the major contributing factors here. In another case, we reported the $\mathrm{Ng}$ gas bound half-sandwich complexes, $\mathrm{NgMCp}^{+}\left(\mathrm{M}=\mathrm{Be}-\mathrm{Ba} ; \mathrm{Ng}=\mathrm{He}-\mathrm{Rn}, \mathrm{Cp}=\eta^{5}\right.$-cyclopentadienyl anion) [96]. In these cases, the dissociation energy values follow the order as $\mathrm{Ng}-\mathrm{Be}>\mathrm{Ng}-\mathrm{Mg}>\mathrm{Ng}-\mathrm{Ca}$ $>\mathrm{Ng}-\mathrm{Sr}>\mathrm{Ng}$-Ba for a particular $\mathrm{Ng}$ atom, whereas for an $\mathrm{M}$ atom, the dissociation energy gradually increases along He-Rn. Figure 4 displays the deformation densities associated with the two major orbital contributors. In the plot, the electron density is shifted from red to blue. The major orbital contribution is originated from the $\mathrm{Ng}\left(\mathrm{p}_{\sigma}\right) \rightarrow \mathrm{BeCp}^{+} \sigma$-donation, whereas $\mathrm{Ng}\left(\mathrm{p}_{\pi}\right) \rightarrow \mathrm{BeCp}^{+} \pi$-donation is responsible for the next orbital term. The plot of $\nabla^{2} \rho(r)$ also shows electron density accumulated region (pink color) in between $\mathrm{Ng}$ and $\mathrm{Be}$, indicating the covalent bond formation.

We also focused on the next neighbor of Be, boron, which is inherently electron deficient in nature, and therefore, is expected to act as strong electron acceptor from $\mathrm{Ng}$. The $\mathrm{B}_{3}{ }^{+}$cluster is a $\pi$-aromatic system [97]. We tested the $\mathrm{Ng}$ binding ability of this $\mathrm{B}_{3}{ }^{+}$cluster for He-Rn which leads to the formation of $\mathrm{a} \mathrm{B}_{3}(\mathrm{Ng})_{3}{ }^{+}$cluster. The He-B and Ne-B bonds are very weak, but for the heavier $\mathrm{Ng}$ atoms, the $\mathrm{Ng}-\mathrm{B}$ (Ar-Rn) bonds are significantly strong (ranging 7.0-13.1, 14.0-32.0, and 24.4-53.2 $\mathrm{kcal} \cdot \mathrm{mol}^{-1} \mathrm{for}^{-}$ the third, second, and first $\mathrm{Ng}$-B bonds, respectively). The strong interaction is also reflected from the corresponding WBI values of 0.57-0.95. Further, the contour plot of $\nabla^{2} \rho(r)$, and EDA-NOCV results show that the Ng-B (Ar-Rn) bonds can be designated as covalent (Figure 4). Later, another computational work by $\mathrm{Li}$ and co-workers revealed that $\mathrm{B}_{\mathrm{n}}{ }^{(\mathrm{n}-2)+}$ clusters could be able to bind with $\mathrm{nNg}$ atoms and the results corroborate our findings [98-100]. 
Plots of Laplacian of Electron Density $\left(\nabla^{2} \rho(r)\right)$
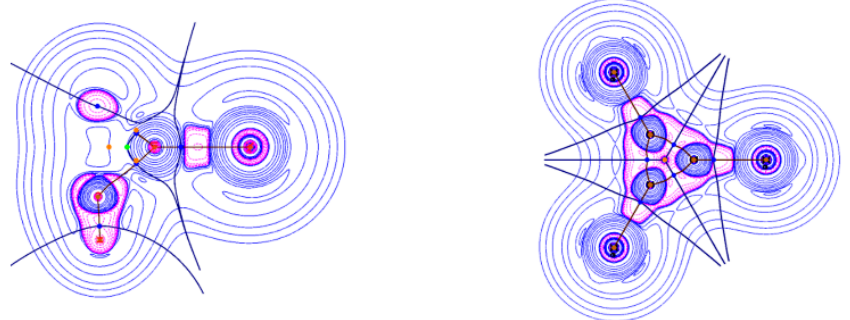

Plots of Deformation Density $(\Delta \rho(r))$

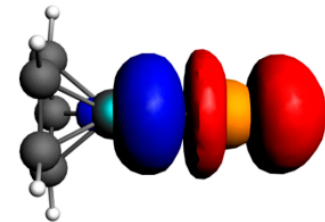

$\mathrm{Ng}(\mathrm{Xe}) \rightarrow \mathrm{BeCp}^{+} \sigma$-Donation

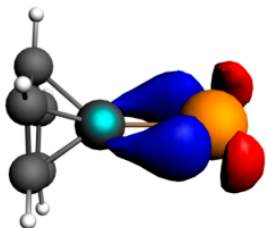

$\mathrm{Ng}(\mathrm{Xe}) \rightarrow \mathrm{BeCp}^{+} \pi$-Donation

$\mathrm{NgBeCp} p^{+}$

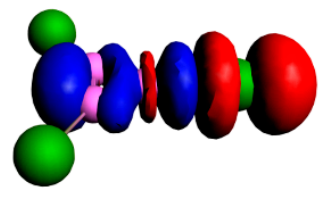

$\mathrm{Ng}(\mathrm{Xe}) \rightarrow \mathrm{B}_{3} \mathrm{Ng}_{2}{ }^{+} \sigma$-Donation

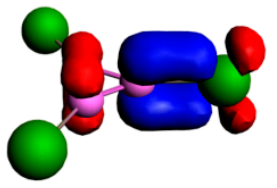

$\mathrm{Ng}(\mathrm{Xe}) \leftarrow \mathrm{B}_{3} \mathrm{Ng}_{2}{ }^{+} \pi$-Back Donation

Figure 4. The contour plots of Laplacian of electron density in $\mathrm{Ng}_{3} \mathrm{~B}_{3}{ }^{+}$complex (pink for negative values and blue for positive values) and deformation density plots in $\mathrm{NgBeCp}^{+}$and $\mathrm{Ng}_{3} \mathrm{~B}_{3}{ }^{+}$. Electron density moves from red to blue region. This figure is reprinted with permission from [96], copyright 2017 American Chemical Society. Part of the figure is also reproduced from [97] with permission with permission from The Royal Society of Chemistry.

Next, we examined the $\mathrm{Ng}$-binding ability of group 14 elements. The cationic $\mathrm{EX}_{3}{ }^{+}(\mathrm{E}=$ group 14 elements, $\mathrm{X}=\mathrm{H}, \mathrm{F}, \mathrm{Cl}, \mathrm{Br}$ ) were also found to have strong $\mathrm{Ng}$ binding ability, albeit lower than the boron centers in $\mathrm{B}_{3}{ }^{+}[101,102]$. For a given $\mathrm{Ng}, \mathrm{EH}_{3}{ }^{+}$follows the $\mathrm{Ng}$ binding order $\mathrm{C}>\mathrm{Si}>\mathrm{Ge}$. For $\mathrm{Sn}$ and $\mathrm{Pb}$ cases, $D_{3 \mathrm{~h}}$ symmetric $\mathrm{EH}_{3}{ }^{+}$is not a global minimum, rather $\mathrm{EH} \cdots \mathrm{H}_{2}{ }^{+}$is the most viable one. In the replacement of $-\mathrm{H}$ by $-\mathrm{X}(\mathrm{X}=\mathrm{F}, \mathrm{Cl}, \mathrm{Br})$, two opposing effects, viz., the -I (inductive) effect of $X$ would enhance the Lewis acidity of $\mathrm{E}$ and $\mathrm{X} \rightarrow \mathrm{E} \pi$-back-donation would diminish its $\mathrm{Ng}$ binding ability. The overall situation would depend on the balance between these two factors. $\mathrm{EF}_{3}{ }^{+}(\mathrm{E}=\mathrm{Si}$, $\mathrm{Ge}$ ) was noted to have increased $\mathrm{Ng}$ binding ability compared to the corresponding $\mathrm{EH}_{3}{ }^{+}$. However, because of the very efficient $\mathrm{F} \rightarrow \mathrm{C} \pi$-back-donation in $\mathrm{CF}_{3}{ }^{+}$, it has significantly lower ability to interact with $\mathrm{Ng}$ in comparison to $\mathrm{CH}_{3}{ }^{+}$. It is also shown that the $\mathrm{EH}_{3}{ }^{+}(\mathrm{E}=\mathrm{Si}, \mathrm{Ge})$ and $\mathrm{EF}_{3}{ }^{+}(\mathrm{E}=\mathrm{Si}-\mathrm{Pb})$, can bind with two Ngs effectively at the same time. The large Lewis acidity for this group of systems was also found for the Lewis base CO [103].

Apart from these main group elements, we have also studied the possibility of transition metal compounds bonding with $\mathrm{Ng}$. A series of superhalogen molecules with general formula $\mathrm{MF}_{3}(\mathrm{M}=$ $\mathrm{Ru}, \mathrm{Os}, \mathrm{Rh}, \mathrm{Ir}, \mathrm{Pd}, \mathrm{Pt}, \mathrm{Ag}, \mathrm{Au}$ ) was considered and their Xe binding ability was tested. Among this series, in terms of bond dissociation energy, $\mathrm{RuF}_{3}$ and $\mathrm{AuF}_{3}$ are the best and second best candidates to bind Xe [104]. Thereafter, in a series of studies, we found that the complete series, $\mathrm{Cu}, \mathrm{Ag}$, and $\mathrm{Au}$, exhibits remarkable $\mathrm{Ng}$ binding ability, which is, in general, larger than the other transition metals. At first, we considered the $\sigma$-aromatic triangular $\mathrm{M}_{3}{ }^{+}(\mathrm{M}=\mathrm{Cu}, \mathrm{Ag}, \mathrm{Au})$ clusters and the possibility of forming $\mathrm{M}_{3}(\mathrm{Ng})_{3}{ }^{+}$complexes [105]. The $\mathrm{Ng}-\mathrm{M}$ bond dissociation energies that range within 2.2-19.0 $\mathrm{kcal} \cdot \mathrm{mol}^{-1}$ follow a descending order of $\mathrm{Au}>\mathrm{Cu}>\mathrm{Ag}$, for a given $\mathrm{Ng}$ atom. In contrast to the 
main group elements, where the orbital contribution is found to be the dominant term, the Ng-M bond for these cases is supported by both Coulombic and covalent contributions in almost equal strength. In the orbital term, the major contributing factor that stabilizes the $\mathrm{Ng}-\mathrm{M}$ bonds is the electron donation from one of the filled $p$-orbitals of $\mathrm{Ng}$-atoms to the LUMO of $\mathrm{M}_{3}{ }^{+}$clusters. In subsequent studies, rather strong 'noble-noble' interaction was understood through the analysis of $\mathrm{NgMNO}_{3}$, $\mathrm{NgCu}\left(\mathrm{NO}_{3}\right)_{2}, \mathrm{NgMSO}_{4}, \mathrm{Ng}_{2} \mathrm{M}_{2} \mathrm{SO}_{4}, \mathrm{NgCuCO}_{3}, \mathrm{Ng}_{2} \mathrm{M}_{2} \mathrm{CO}_{3}, \mathrm{NgMCN}, \mathrm{NgMO}$, and monocationic $\mathrm{Ng}$ bound M-bipyridine [Ng-M(bipy] ${ }^{+}$complexes $(\mathrm{Ng}=\mathrm{Ar}-\mathrm{Rn} ; \mathrm{M}=\mathrm{Cu}, \mathrm{Ag}$, $\mathrm{Au}$ ) [106-110]. A partial covalent character of the Ng-M bonds $(\mathrm{Ng}=\mathrm{Ar}-\mathrm{Rn})$ was understood via the electron density and EDA-NOCV analyses. For [Ng-M(bipy] $]^{+}$, a major demand to synthesize these cationic complexes is to find a suitable counterion that can stabilize the whole complex without weakening the $\mathrm{Ng}-\mathrm{M}$ bonds. The $\left[\mathrm{SbF}_{6}\right]^{-}$anion was noted to serve this purpose well. For further information about the advancement in the field of noble metal noble gas chemistry, readers are referred to a recent review [111].

\subsection{Insertion Complexes of XNgY Type}

Another widely studied class of $\mathrm{Ng}$ compounds are the $\mathrm{XNgY}$ type where the $\mathrm{Ng}$ is inserted within an $X-Y$ bond (see Figure 5 for the systems reported by us). So far, in literature a good number of $\mathrm{Kr}$ and Xe inserted compounds were isolated in low-temperature matrices [34,36,40], while HArF is the only example for Ar insertion [23]. There is still no experimental report of He or Ne insertion compounds.
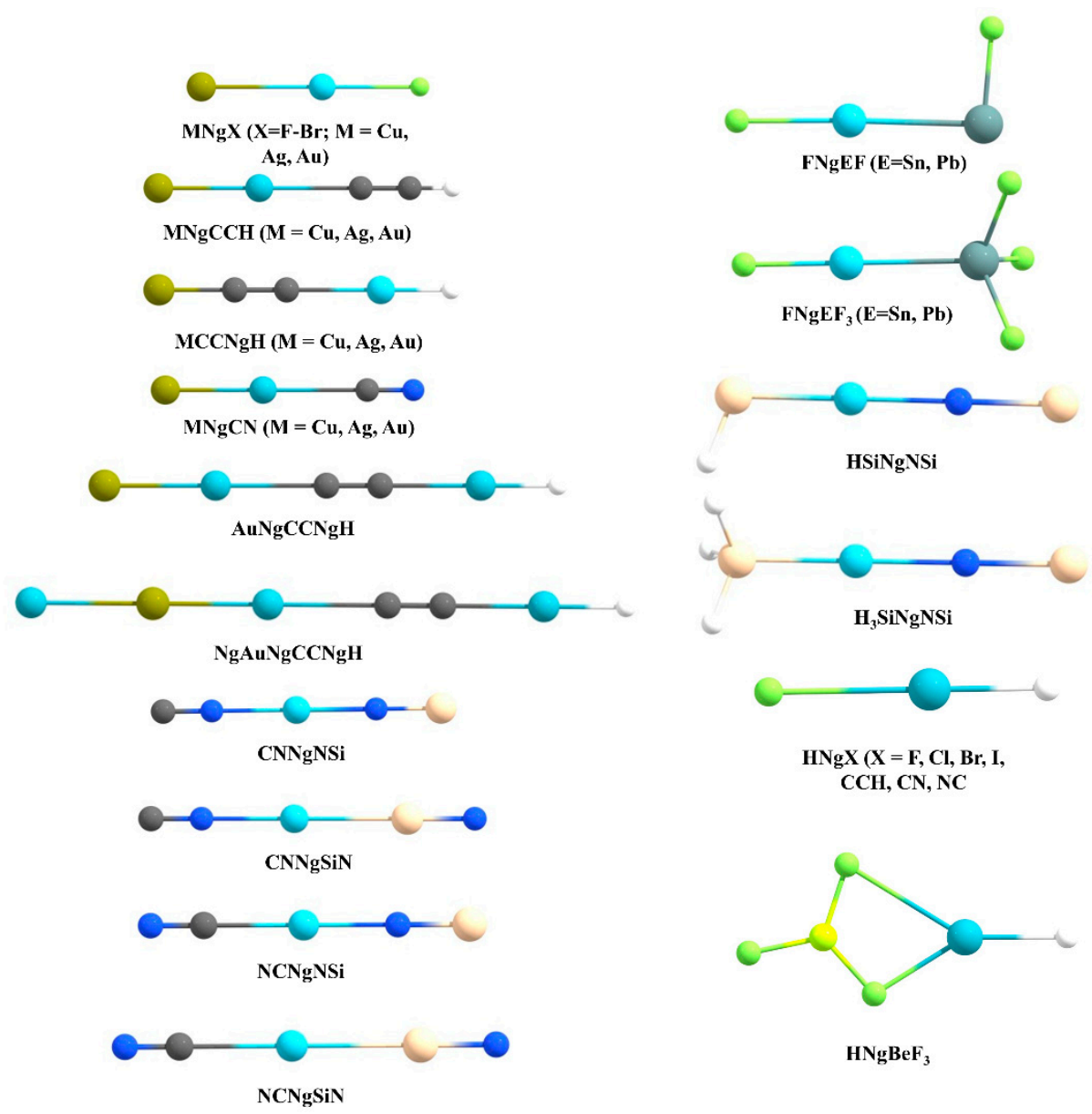

$\mathrm{HNgX}(\mathrm{X}=\mathrm{F}, \mathrm{Cl}, \mathrm{Br}, \mathrm{I}$ $\mathrm{CH}, \mathrm{CN}, \mathrm{NC}$

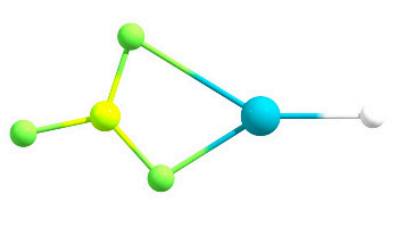

$\mathrm{HNgBeF}_{3}$

Figure 5. The structures of the XNgY type systems reported by us.

In comparison to the $\mathrm{NgXY}$ type, there are some basic differences in the stability of this category. The stability in the former is dictated by the thermodynamic norms of $\mathrm{Ng}$ - $\mathrm{X}$ bonds. A strong polarizing center always shows strong donor-acceptor interaction with $\mathrm{Ng}$ atoms. On the other hand, the stability 
of $\mathrm{XNgY}$ type of compounds is not straightforward as the formation of such molecules needs to compromise the $\mathrm{X}-\mathrm{Y}$ interaction. Because of the lower reactivity of $\mathrm{Ng}$, in no cases can the sum of $\mathrm{X}-\mathrm{Ng}$ and $\mathrm{Ng}-\mathrm{Y}$ interactions compensate the $\mathrm{X}-\mathrm{Y}$ interaction. Therefore, such molecules are not thermochemically stable species, and rather their existence is driven by kinetics. Generally, for these cases, a large number of dissociation paths need to be considered. The thermochemical studies show that except for the two dissociation channels (shown below), others are highly (or at least moderately) endergonic in nature showing the stability of $\mathrm{XNgY}$. The two most competing dissociation paths are: (i) two-body (2B) dissociation path: $\mathrm{XNgY} \rightarrow \mathrm{Ng}+\mathrm{XY}$ and (ii) three-body (3B) dissociation path: $\mathrm{XNgY}$ $\rightarrow \mathrm{X}+\mathrm{Ng}+\mathrm{Y}$. In general, the $2 \mathrm{~B}$ dissociation channel is highly exergonic in nature, whereas the 3B dissociation occasionally becomes slightly exergonic at room temperature. Therefore, to comment on the stability of $\mathrm{XNgY}$, one should check the activation energy barrier for these paths (see Figure 6). While in most of the cases single reference-based methods are quite reliable to study the transition state (TS) for 2B dissociation, the computation for the barrier of 3B dissociation is complicated as simultaneous bond-breaking that often requires multireference treatment, and, therefore it is hard to evaluate for slightly larger systems. Best systems are those for which the 3-B dissociation path becomes endergonic in nature, at least at low temperatures. Hu and co-workers [112] showed by computations that the half-life of XNgY type of $\mathrm{Ng}$ compounds depends on the energy barrier height. An XNgY system with a minimum energy barrier of 6,13 , and $21 \mathrm{kcal} \cdot \mathrm{mol}^{-1}$ would have a half-life in the order of $\sim 10^{2} \mathrm{~s}$ at 100,200 and $300 \mathrm{~K}$, respectively.

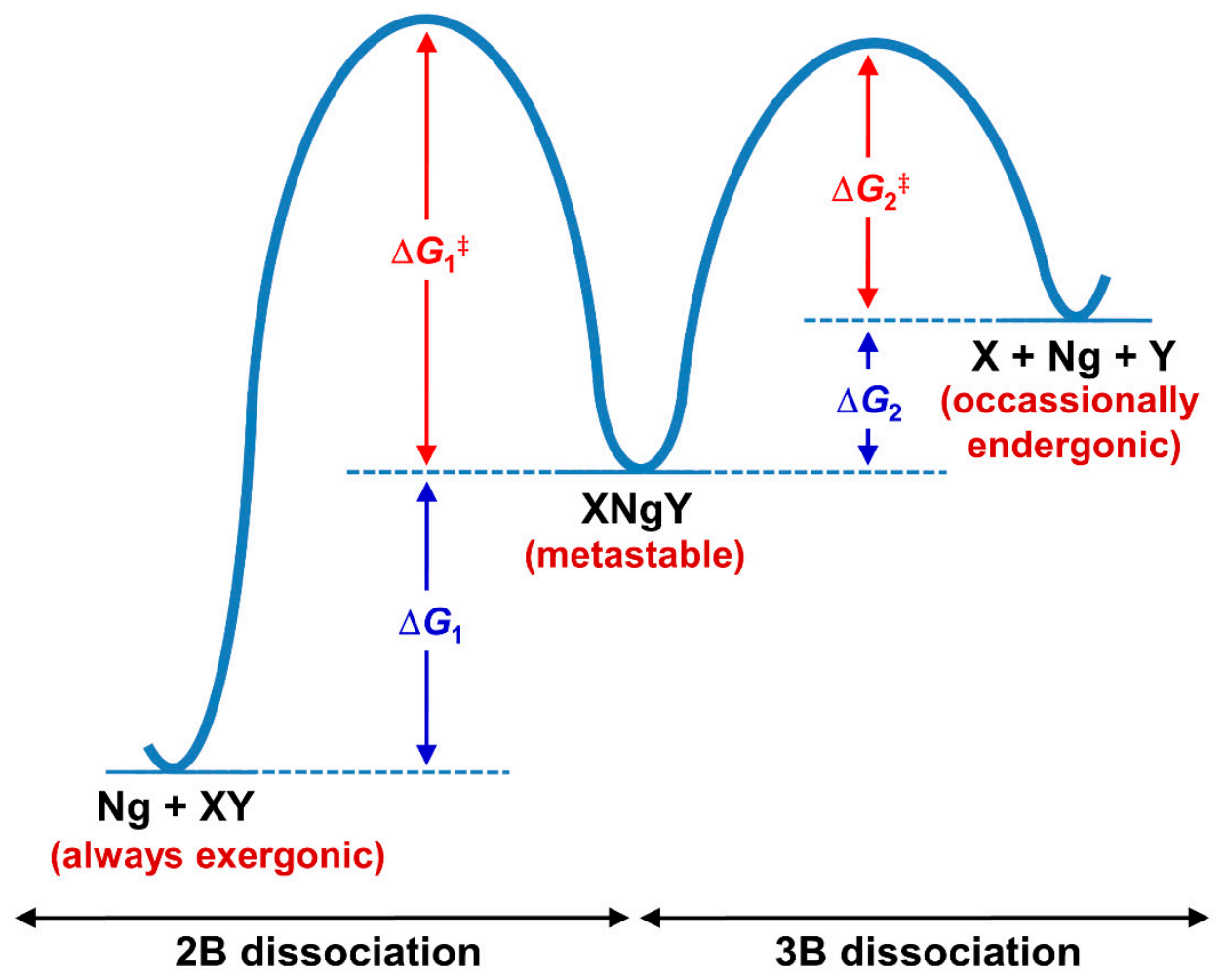

Figure 6. The schematic representation of the $2 \mathrm{~B}$ and $3 \mathrm{~B}$ dissociation paths of $\mathrm{XNgY}$.

In a couple of studies, Merino and co-workers [113,114] studied the bonding situation of $\mathrm{HNgY}$ $(\mathrm{Y}=\mathrm{F}, \mathrm{Cl}, \mathrm{Br}, \mathrm{I}, \mathrm{CCH}, \mathrm{CN}, \mathrm{NC} ; \mathrm{Ng}=\mathrm{Xe}, \mathrm{Rn})$ molecules where the $\mathrm{H}-\mathrm{Ng}$ bonds were found to be electron-shared bond and $\mathrm{Ng}-\mathrm{Y}$ was an ionic bond. Overall, the molecules might be considered as the interaction between $\mathrm{Ng}^{+}$and $\left[\mathrm{H}^{\cdots} \mathrm{Y}\right]^{-}$that form a polar electron-shared bond. Both the molecules are metastable in nature having sizable kinetic protection against dissociation: $\mathrm{HNgY} \rightarrow \mathrm{Ng}$ + HY. Thereafter, some of us showed that $\mathrm{H}_{3} \mathrm{SiNSi}$ and HSiNSi molecules can also form $\mathrm{Ng}$ insertion compounds like $\mathrm{H}_{3} \mathrm{SiNgNSi}$ and $\mathrm{HSiNgNSi}(\mathrm{Ng}=\mathrm{Xe}, \mathrm{Rn})$, respectively [115]. The free energy change 
( $\Delta G$; computed at $298 \mathrm{~K}$ and $1 \mathrm{~atm}$ ) associated with the $2 \mathrm{~B}$ dissociation channel producing the free $\mathrm{Ng}$ and parent molecule is negative in both the cases. On the other hand, the $3 \mathrm{~B}$ dissociation path is endergonic for the Rn analogues but slightly exergonic (small negative $\Delta G$ ) in the case of Xe, though computations at lower temperatures make this process endergonic. Negative $\nabla^{2} \rho\left(r_{c}\right)$ and $H\left(r_{c}\right)$ values and high electron localization function (ELF) at Si-Ng BCP reflect the covalent nature of bonding, whereas Ng-N bond is of ionic type (see Figure 7). In fact, the systems could be best represented as $\left(\mathrm{H}_{3} \mathrm{SiNg}\right)^{+}(\mathrm{NSi})^{-}$and $(\mathrm{HSiNg})^{+}(\mathrm{NSi})^{-}$as revealed by $\mathrm{NBO}$ analysis. EDA also corroborates this argument where the Si-Ng bond is dominantly supported by $\Delta E_{\text {orb }}$, whereas in the $\mathrm{Ng}-\mathrm{N}$ bond the $\Delta E_{\text {elstat }}$ contribution is substantial. The computed activation energy barriers suggest that the $\mathrm{H}_{3} \mathrm{SiNgNSi}$ is kinetically stable enough to be detected at the $250-300 \mathrm{~K}$ temperature range, whereas HSiNgNSi needs a lower temperature range (150-200 K) to be detected.
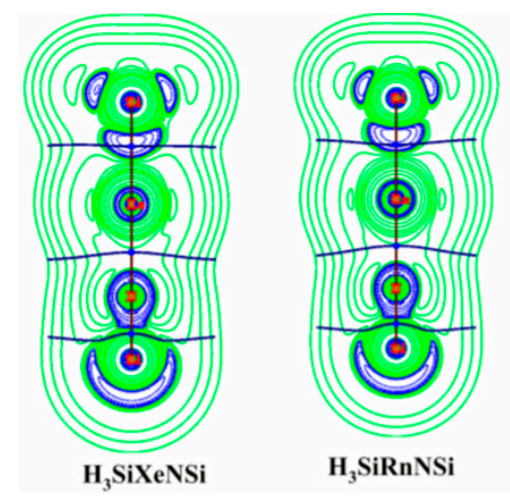

(a)

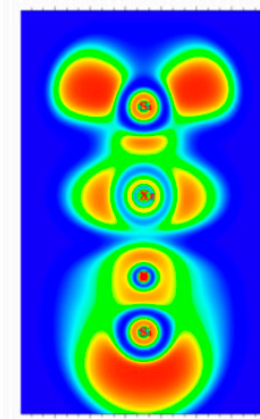

$\mathrm{H}_{3} \mathrm{SiXeNSi}$

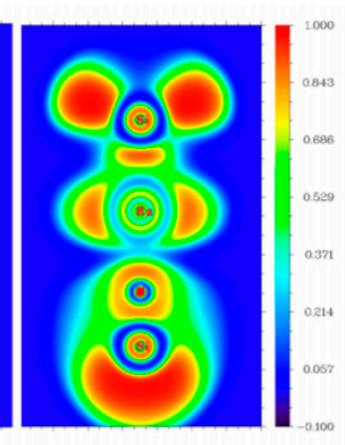

$\mathrm{H}_{3}$ SiRnNSi

(b)

Figure 7. Contour plots of (a) Laplacian of electron density and (b) electron localization function of $\mathrm{H}_{3} \mathrm{SiNgNSi}(\mathrm{Ng}=\mathrm{Xe}, \mathrm{Rn})$.

We extended our work in this category of $\mathrm{Ng}$ compounds with the report of the first set of compounds having E-Ng $(\mathrm{E}=\mathrm{Sn}, \mathrm{Pb})$ covalent bonds, particularly $\mathrm{FNgEF}_{3}$ and $\mathrm{FNgEF}(\mathrm{E}=\mathrm{Sn}, \mathrm{Pb}$; $\mathrm{Ng}=\mathrm{Kr}, \mathrm{Xe}, \mathrm{Rn}$ ) molecules [116]. They are found to be metastable in nature, where only $\mathrm{FNgEF}_{3} \rightarrow$ $\mathrm{Ng}+\mathrm{EF}_{4}$ and $\mathrm{FNgEF} \rightarrow \mathrm{Ng}+\mathrm{EF}_{2}$ are highly exergonic, but they are protected by an energy barrier of $23.9-49.9 \mathrm{kcal} \cdot \mathrm{mol}^{-1}$ for the former case and $2.2-8.7 \mathrm{kcal} \cdot \mathrm{mol}^{-1}$ in the latter system, with a gradual increase from $\mathrm{Kr}$ to $\mathrm{Rn}$. The natural charge distribution, corresponding $H\left(r_{c}\right)$ values, and the EDA computations conclude the covalent character in $\mathrm{Ng}$-E bonds and an ionic description in $\mathrm{Ng}$-F bonds.

A recent work by Samanta reported superhalogen $\left(\mathrm{BO}_{2}, \mathrm{BF}_{4}\right)$-supported $\mathrm{Ng}$ insertion compounds, $\operatorname{HNgY}\left(\mathrm{Y}=\mathrm{BO}_{2}, \mathrm{BF}_{4}\right)$ which are more stable than their halogen analogues [117]. Therefore, a superhalogen is a more efficient candidate than a halogen to form $\mathrm{Ng}$ insertion compounds. As reflected above, the Be center has an excellent capability to form viable non-insertion type regular $\mathrm{Ng}$ compounds which prompts us to study the performance of the Be-based superhalogen $\mathrm{BeF}_{3}$ in stabilizing the $\mathrm{HNgBeF}_{3}(\mathrm{Ng}=\mathrm{Ar}-\mathrm{Rn})$ compounds [118]. Between the $2 \mathrm{~B}\left(\mathrm{HNgBeF}_{3} \rightarrow \mathrm{Ng}+\mathrm{HBeF}_{3}\right)$ and $3 \mathrm{~B}\left(\mathrm{HNgBeF}_{3} \rightarrow \mathrm{H}+\mathrm{Ng}+\mathrm{BeF}_{3}\right)$ dissociation paths, $2 \mathrm{~B}$ dissociation one is exergonic whereas the $3 \mathrm{~B}$ dissociation option is endergonic. Another pathway $\left(\mathrm{HNgBeF}_{3} \rightarrow \mathrm{Ng}+\mathrm{HF}+\mathrm{BeF}_{2}\right)$ is also exergonic, but careful observation leads us that this is not a single step process rather than two as, $\mathrm{HNgBeF}_{3} \rightarrow \mathrm{Ng}+\left(\mathrm{HBeF}_{3}\right) \rightarrow \mathrm{Ng}+\left(\mathrm{HF}+\mathrm{BeF}_{2}\right)$. The barriers for the $2 \mathrm{~B}$ dissociation processes are 1.0-13.9 $\mathrm{kcal} \cdot \mathrm{mol}^{-1}$ for Ar to Rn compounds. The Xe and Rn analogues might be stabilized through a half-life of $10^{2} \mathrm{~s}$ up to $100 \mathrm{~K}$ temperature. Thorough bonding analysis shows that the $\mathrm{H}-\mathrm{Ng}$ bonds are of covalent type, whereas the $\mathrm{Ng}$-F interactions are of ionic-type and the molecule could be best represented as $(\mathrm{HNg})^{+}\left(\mathrm{BeF}_{3}\right)^{-}$.

Next, we reported a special system, $\mathrm{NCNgNSi}(\mathrm{Ng}=\mathrm{Kr}, \mathrm{Xe}, \mathrm{Rn})$, which represents the first case of a covalently bound C-Ng-N unit [119]. $\mathrm{XNgY}$ insertion molecules are, in general, represented as 
$\mathrm{X}^{+}(\mathrm{NgY})^{-}$. However, these molecules feature the unprecedented case where both $\mathrm{C}-\mathrm{Ng}$ and $\mathrm{Ng}-\mathrm{N}$ bond can be represented by an electron-shared bond. Except for a $2 \mathrm{~B}$ dissociation path, $\mathrm{NCNgNSi} \rightarrow \mathrm{Ng}+$ $\mathrm{CNSiN}$, all other dissociation channels are endergonic for Xe and Rn analogues. For NCKrNSi the 3B dissociation channel producing $\mathrm{CN}, \mathrm{Kr}$, and $\mathrm{NSi}$, is slightly exergonic at $298 \mathrm{~K}$, thus a lower temperature will make this dissociation channel endergonic. The free energy barrier for the $2 \mathrm{~B}$ dissociation ranges from $25.2-39.3 \mathrm{kcal} \cdot \mathrm{mol}^{-1}$ for $\mathrm{Kr}$ to $\mathrm{Rn}$ analogues, with a gradual increase along $\mathrm{Kr}-\mathrm{Rn}$ is obtained. Thus, the $\mathrm{NCNgNSi}(\mathrm{Ng}=\mathrm{Xe}, \mathrm{Rn})$ systems are viable and may be detected under ambient conditions, whereas the $\mathrm{Kr}$ analogue would be detectable at low temperature. The simultaneous existence of $\mathrm{C}-\mathrm{Ng}$ and $\mathrm{Ng}-\mathrm{N}$ covalent bonds is confirmed from the sizable WBI value $(>0.5)$, negative $H\left(r_{c}\right)$ values, and the EDA computations. In the latter analysis, the size of the $\Delta E_{\text {orb }}$ term is a very useful indicator to justify which fragmentation scheme is the best to represent the electronic structure of the overall molecule. The one, which results in the lowest $\Delta E_{\text {orb }}$ value, is the best to describe the bonding of the molecule as it needs the least change in charge distribution to get the electronic structure of the molecule $[120,121]$. For both $\mathrm{C}-\mathrm{Ng}$ and $\mathrm{Ng}-\mathrm{N}$ bonds, we tested both neutral (electron-shared) and ionic schemes, and in either case the neutral scheme results in the lowest $\Delta E_{\text {orb }}$ value. AdNDP analysis further corroborates this description which identifies a delocalized $3 c-2 e \sigma-$-bond within the $\mathrm{C}-\mathrm{Ng}-\mathrm{N}$ moiety and a totally delocalized $5 c-2 e \sigma$-bond in these molecules (see Figure 8). Another interesting fact is that the dissociation of $\mathrm{Ng}$ from $\mathrm{NCNgNSi}$ produces a higher energy isomer, CNSiN, rather than the most stable parent moiety NCNSi. As such the NCNSi $\rightarrow$ CNSiN process needs to cross a very high barrier, but in the presence of $\mathrm{Ng}$ it gets reduced substantially, hence, $\mathrm{Ng}$ could facilitate the detection of the high energy isomer of NCNSi.
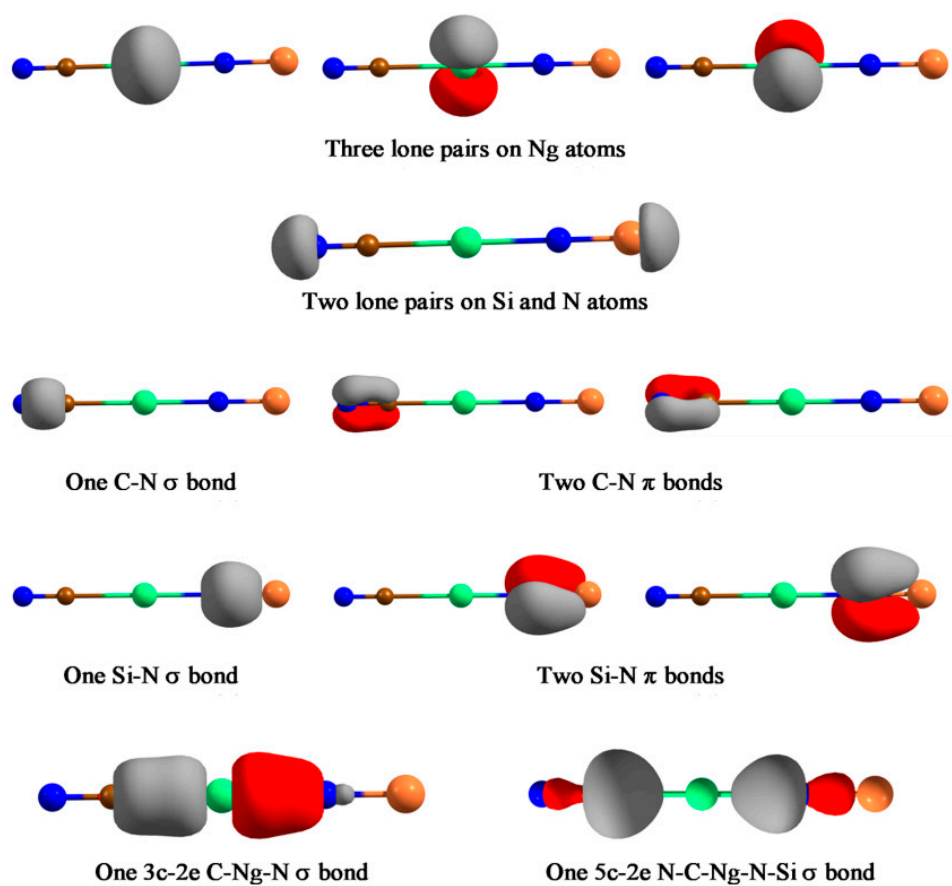

Figure 8. The bonding elements recovered by the AdNDP analysis for NCNgNSi $(\mathrm{Ng}=\mathrm{Kr}-\mathrm{Rn})$ compounds. The occupation numbers in all cases are very closed to 2.00 . This figure is reproduced from [119].

Apart from the main group elements, we have also extended our work to transition metal systems. Transition metal acetylides ( $\mathrm{MCCH} ; \mathrm{M}=\mathrm{Cu}, \mathrm{Ag}$, $\mathrm{Au}$ ) are excellent in forming Ng insertion- type compounds. $\mathrm{Ng}$ atoms can be inserted into $\mathrm{C}-\mathrm{H}$ and/or M-C bonds in the MCCH molecules [122,123]. The $\mathrm{MNgCCH}(\mathrm{Ng}=\mathrm{Xe}, \mathrm{Rn})$ [123] complexes are the first set of examples having M-Ng-C motif in the chemical literature. The isomerization process, $\mathrm{MNgCCH} \rightarrow \mathrm{NgMCCH}$, i.e., insertion to non-insertion type, is exergonic in nature. Except for the Ag analogues, the 3B dissociation channels are endergonic 
in nature. The computed barrier shows that these complexes are indeed viable. The $\mathrm{M}-\mathrm{Ng}$ and $\mathrm{Ng}-\mathrm{C}$ bonds are covalent and ionic in nature, respectively. The best representation of the complexes is $(\mathrm{MNg})^{+}(\mathrm{CCH})^{-}$. Another possible position for $\mathrm{Ng}$ insertion in $\mathrm{MCCH}$ is within $\mathrm{C}-\mathrm{H}$ bondz which results in the formation of $\mathrm{MCCNgH} \mathrm{[122].} \mathrm{Here,} \mathrm{the} \mathrm{bonding} \mathrm{analysis} \mathrm{indicates} \mathrm{that} \mathrm{the} \mathrm{H}-\mathrm{Ng}$ bond is covalent in nature whereas the $\mathrm{Ng}-\mathrm{C}$ bond has a partially covalent character. Furthermore, two Xe inserted analogues, $\mathrm{AuXeCCXeH}$ complex and the three Xe bond system, $\mathrm{XeAuXeCCXeH,} \mathrm{might} \mathrm{also}$ be viably detected in a low-temperature matrix. In a subsequent study, the possibility of $\mathrm{Ng}$ insertion into the $\mathrm{M}-\mathrm{C}$ bonds of metal cyanides (MCN) resulting in the compounds with the formula, $\mathrm{MNgCN}$ $(\mathrm{M}=\mathrm{Cu}, \mathrm{Ag}, \mathrm{Au} ; \mathrm{Ng}=\mathrm{Xe}, \mathrm{Rn})$ was carried out [124]. The compounds $\mathrm{MNgCN}$ are thermochemically stable with respect to all possible dissociation paths, except for two 2B dissociation processes, viz., $\mathrm{MNgCN} \rightarrow \mathrm{Ng}+\mathrm{MCN}$ and $\mathrm{MNgCN} \rightarrow \mathrm{Ng}+\mathrm{MNC}$. These two dissociation paths can be further connected with the internal rotation of $[\mathrm{MNg} \leftrightarrow \mathrm{NgM}]$ and $[\mathrm{CN} \leftrightarrow \mathrm{NC}]$ as in, $\mathrm{MNgCN} \rightarrow \mathrm{NgMCN}$ and $\mathrm{MNgCN} \rightarrow \mathrm{NgMNC}$, respectively. These processes are kinetically protected by substantial nergy barriers $\left(11.8-15.4 \mathrm{kcal} \cdot \mathrm{mol}^{-1}\right.$ for $\mathrm{Cu}, 9.8-13.6 \mathrm{kcal} \cdot \mathrm{mol}^{-1}$ for $\mathrm{Ag}$, and $19.7-24.7 \mathrm{kcal} \cdot \mathrm{mol}^{-1}$ for $\left.\mathrm{Au}\right)$. The former process occurs in two steps via an intermediate $\mathrm{MNgNC}$, whereas the latter one is a single step process. $\mathrm{NgMNC}$ can isomerize into a more stable $\mathrm{NgMCN}$, but a certain energy barrier protects it. The process involves two steps for $\mathrm{Cu}$ but single step for $\mathrm{Ag}$ and $\mathrm{Au}$ analogues, and most importantly corresponding barrier enhances in comparison to that in bare MNC $\rightarrow \mathrm{MCN}$ process (see Figure 9).

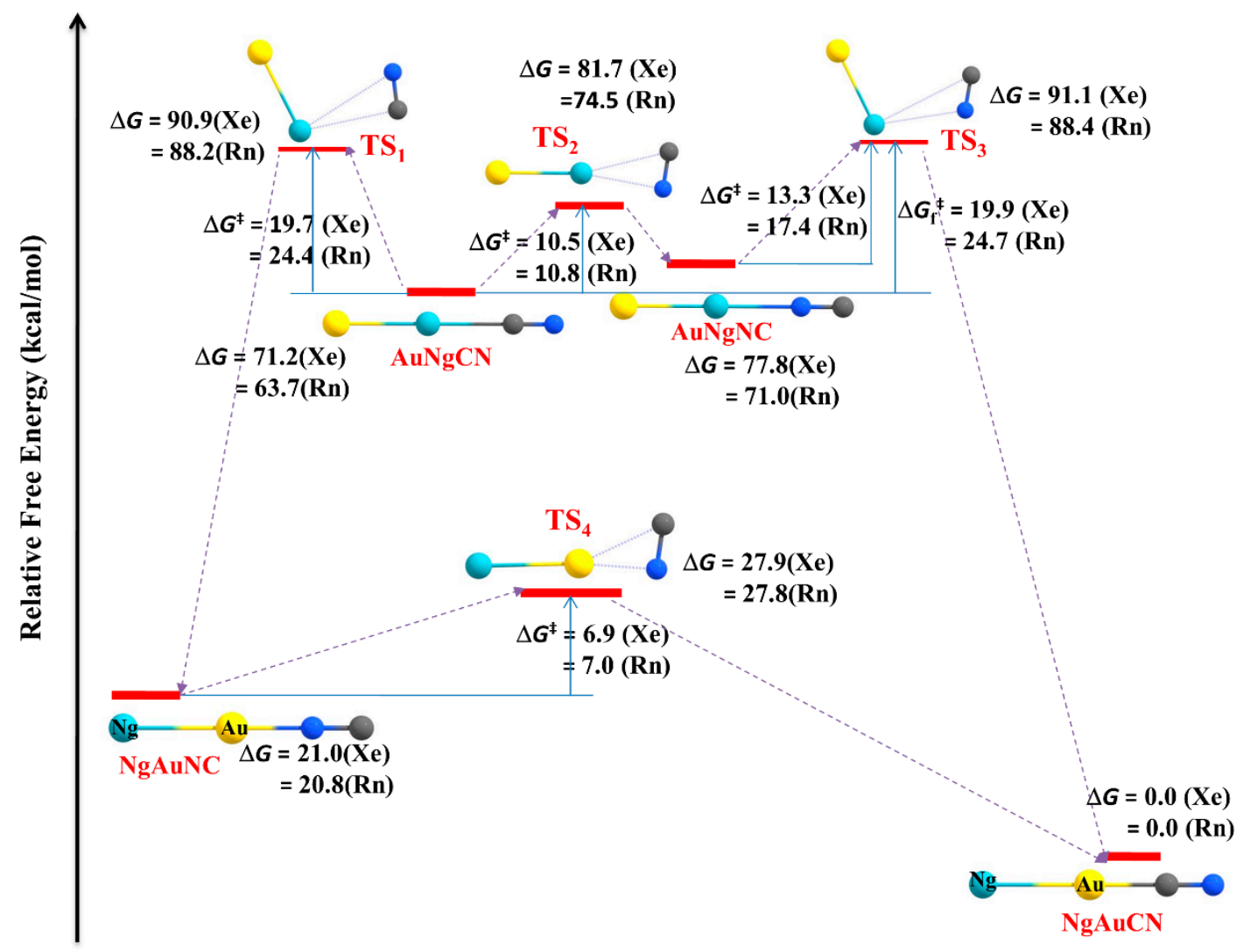

Figure 9. The isomeric transformation occurred in $\mathrm{AuNgCN}$ molecules to be converted into the most stable $\mathrm{NgAuCN}$ form studied at the MPW1B95/cc-pVTZ/cc-pVTZ-PP level. Relative free energies with respect to the most stable $\mathrm{NgAuCN}$ isomer in $\mathrm{kcal} \cdot \mathrm{mol}^{-1}$. This figure is reproduced from [123] with permission from the Centre National de la Recherche Scientifique (CNRS) and The Royal Society of Chemistry. 


\subsection{Ng-Encapsulated Cage Complexes}

The effects of confinement on quantum-chemical entities change their physical and chemical properties up to a certain extent. Special restrictions applied since the confinement changes the electronic energy levels, linear and non-linear optical properties, nature of bonding, the selectivity of chemical reactions, etc. The particle-in-a-box is the long-known pedagogical problem that every chemistry student learns. A real-life observation is the formation of endo product between the reaction of 9-hydroxymethylanthrancene and N-cyclohexylphthalimide in presence of $\mathrm{Pd}(\mathrm{II})$ self-assembled coordination cages [125].

Confinement affects the bonding between two Ng-atoms. Fullerenes are one of the most studied cavitands that have been used to study the effects of confinement. Particularly, $\mathrm{C}_{60}$ is used to trap two $\mathrm{Ng}$ atoms in $\mathrm{Ng}_{2} @ \mathrm{C}_{60}(\mathrm{Ng}=\mathrm{He}, \mathrm{Ne}, \mathrm{Ar}, \mathrm{Kr})[126,127]$ (see Figure 10 for the structures of all $\mathrm{Ng}$ - encapsulated cage complexes reported by us). Krapp and Frenking [126] showed that because of confinement within $\mathrm{C}_{60}$, the bond distance in $\mathrm{Xe}_{2}$ even becomes smaller than that in free $\mathrm{Xe}_{2}{ }^{2+}$. Bonding analysis reveals that because of strong steric pressure exerted by the host, two $\mathrm{Ng}$ atoms come closer to each other which results in a strong enough orbital involvement to give negative $H\left(r_{\mathrm{c}}\right)$ values at the $\mathrm{BCP}$ of $\mathrm{Ng}-\mathrm{Ng}$ bond for $\mathrm{Ng}=\mathrm{Ar}, \mathrm{Kr}$, Xe with gradually larger negative values in going from $\mathrm{Ar}$ to $\mathrm{Xe}$. By comparing the reactivity of the encapsulated $\mathrm{Ng}_{2}$ with the free one, they concluded that the $\mathrm{Ng}-\mathrm{Ng}$ bond in $\mathrm{Ng}_{2} @ \mathrm{C}_{60}$ should be called as a true chemical bond for $\mathrm{Ng}=\mathrm{Ar}-\mathrm{Xe}$, whereas in cases of $\mathrm{Ng}=\mathrm{He}$ and $\mathrm{Ne}$, because of lower sizes the cavity space turns out to be large enough to orient in some distant position in order to minimize the Pauli repulsion between each other and interacting through van der Waals interaction. We complemented this study through our ab initio molecular dynamics study to examine the kinetic stability of $\mathrm{Ng}_{2} @ \mathrm{C}_{60}$ [127]. During our simulation, we perceived the precessional movement of $\mathrm{Ng}_{2}$ inside the $\mathrm{C}_{60}$ cage where $\mathrm{Ng}_{2}$ acts as a single chemical entity which means that no haphazard movement is noted. The movement of two $\mathrm{Ng}$ atoms correlates with each other. This result also supports the formation of some sort of bonding between two $\mathrm{Ng}$ atoms after the confinement. With the increase in the size of the $\mathrm{Ng}$ atom, the extent of such precessional movement diminishes which is because of the facts that with the increasing size of the heavier $\mathrm{Ng}$ atoms, the interaction between that $\mathrm{Ng}$ and carbon atoms of the cage wall also increases and with the larger sizes the reorganization energy of the cage for the movement of $\mathrm{Ng}_{2}$ also increases. In another relevant study, we found that the encapsulation of $\mathrm{Xe}_{2}$ dimer demands so significant structural change in the host $\mathrm{C}_{60}$ moiety that the latter breaks the isolated pentagonal rule (IPR) [128], rather it prefers a geometry having two adjacent pentalene units in order to provide larger space to $\mathrm{Xe}_{2}$ [129].

Then, some of us attempted to even induce a chemical bond between two He atoms by confining in a significantly smaller cavity than $\mathrm{C}_{60}$ [130]. Because of the confinement of two He atoms within $\mathrm{C}_{20} \mathrm{H}_{20}$ dodecahedrane, the shortest He-He internuclear distance of $1.265 \AA$ is attained which is even less than half of the distance in free $\mathrm{He}_{2}$ dimer. Although a very short internuclear distance and a bond path is obtained between two He atoms, negligible charge transfer, essentially zero WBI value and the corresponding plots of $\nabla^{2} \rho(r)$ and molecular orbitals (MOs) suggest a closed-shell interaction between them. Based on this study, the drawn conclusion is that $a$ short internuclear separation does not necessarily imply the existence of a chemical bond. This conclusion also corroborates the argument that a bond path does not necessarily imply a chemical bond [131].

We continued our effort to get a chemically bound $\mathrm{He}_{2}$ unit under a confined situation. We have now tested within $\mathrm{B}_{12} \mathrm{~N}_{12}$ and $\mathrm{B}_{16} \mathrm{~N}_{16}$ cages [132]. Although such encapsulated analogues are thermochemically unstable with respect to dissociation, they are kinetically stable as understood from the ab initio simulations. In these heteroatomic cages, the charge transfer from He to the cage slightly improves in comparison to that in $\mathrm{C}_{20} \mathrm{H}_{20}$. Interestingly, in case of $\mathrm{He}_{2} @ \mathrm{~B}_{12} \mathrm{~N}_{12}$ the $H\left(r_{\mathrm{c}}\right)$ values at the $\mathrm{BCP}$ of He-He bond turns out to be negative $(-0.009 \mathrm{au})$, indicating some sort of orbital (covalent) involvement therein. Further, EDA computation taking two He atoms as two fragments with a frozen distance as in the encapsulated complex reveals that $40.9 \%$ of the total attraction is originated from the $\Delta E_{\text {orb }}$ term which corroborates with the orbital involvement. 
The clathrate hydrate and its HF doped analogue can also encapsulate $\mathrm{Ng}$ atoms [133]. A model study considering $5^{12}, \mathrm{HF}^{12}$ (the HF doped analogues), $5^{12} 6^{8}$ and HF5 ${ }^{12} 6^{8}$ as host cages and Ng $=\mathrm{He}$, $\mathrm{Ne}$, and Ar as target species has been performed thoroughly. The HF doping increases the stability of the cages as well as that of $\mathrm{Ng}$ encapsulated cages. The $5^{12}$ and $\mathrm{HF} 5^{12}$ cages encapsulate one $\mathrm{Ng}$ atom in all cases. The HF5 $5^{12} 6^{8}$ cages can hold up to $10 \mathrm{He}, 6 \mathrm{Ne}$ atoms and $6 \mathrm{Ar}$ atoms depending on the temperatures. The $\mathrm{Ng}-\mathrm{O}, \mathrm{Ng}-\mathrm{F}$, and $\mathrm{Ng}-\mathrm{Ng}$ interactions in these cases are found to be purely noncovalent in nature.

We further extended our work to the cucurbit[n]uril $(\mathrm{CB}[\mathrm{n}])$ taking $\mathrm{CB}[6]$ as a case study. $\mathrm{CB}[\mathrm{n}]$ is well-known for its host-guest chemistry [134-136]. We employed them to encapsulate $\mathrm{Ng}$ atoms as well [137]. $\mathrm{CB}[6]$ could encapsulate up to three $\mathrm{Ne}$ atoms whereas two $\mathrm{Ng}$ ( $\mathrm{Ar}$ and $\mathrm{Kr}$ ) inside the cavity. The larger sizes of $\mathrm{Ar}$ and $\mathrm{Kr}$ as compared to smaller $\mathrm{Ne}$ are responsible for this. The repulsive force between the Ngs and $\mathrm{CB}[6]$ distorts the cage walls. The distances between two Ng atoms are smaller than the summation of their van der Waal's (vdW) radii. The electron density analysis shows that the interactions between the $\mathrm{Ng}$ atoms inside the $\mathrm{CB}[6]$ cage is closed-shell type in nature. The dispersion term is the major contributing one that stabilizes the whole system as revealed by EDA. The molecular dynamics simulations show that at $77 \mathrm{~K}$ the $\mathrm{Ng}$ atoms would remain inside the cage. A similar study was also carried out with octa acid [138].

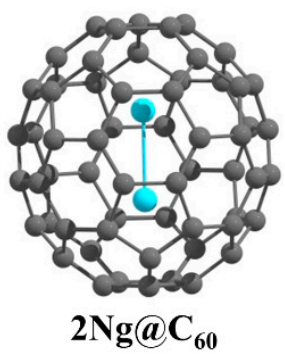

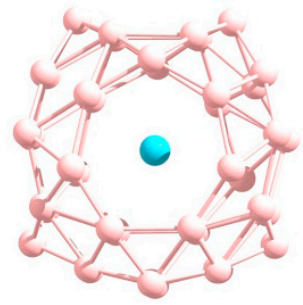

$\mathrm{Ng} @ \mathrm{~B}_{40}$

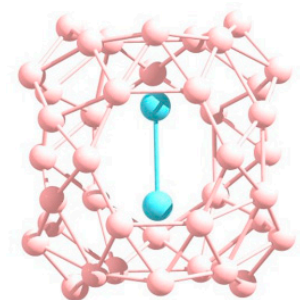

$2 \mathrm{Ng} @ \mathrm{~B}_{40}$

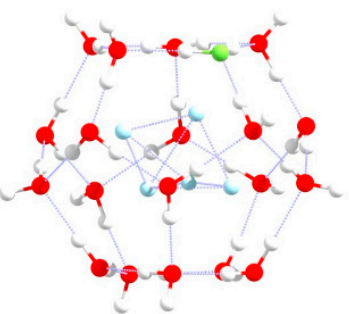

$5 \mathrm{Ng}$ @HF5 ${ }^{12}$

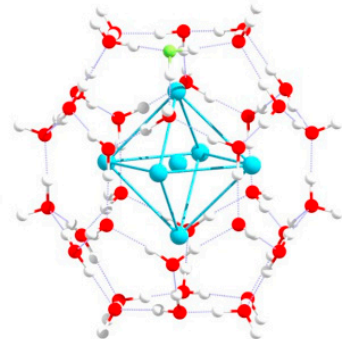

$2 \mathrm{Ng} @ \mathrm{~B}_{12} \mathrm{~N}_{12}$

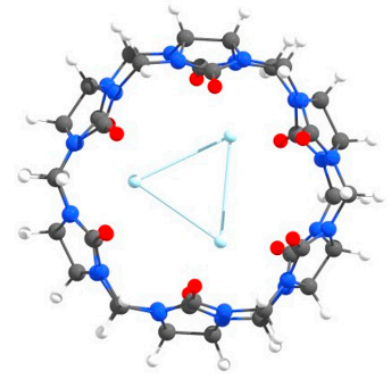

3Ng@CB[6]

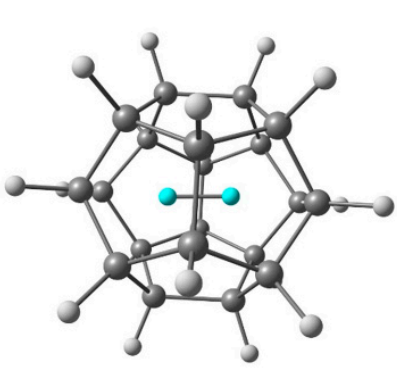

$\mathrm{He}_{2} @ \mathrm{C}_{20} \mathrm{H}_{20}$
$7 \mathrm{Ng} @ \mathrm{HF5}^{12} \mathbf{6}^{8}$

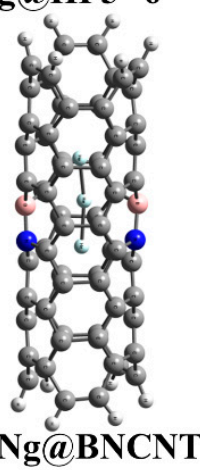

Figure 10. The structures of the Ng-encapsulated cage systems reported by us.

BN-doped carbon nanotubes (BNCNTs) have shown that not only the confinement but also the electronic charge distribution of the cavitand plays an important role in stabilizing $\mathrm{Ng}$ atoms inside the cavity [139]. The He-He bond distance is optimized to be $1.824 \AA$ in $\mathrm{He}_{2} @ \mathrm{BNCNT}_{\text {, which is }}$ surprisingly smaller than that in $\mathrm{He}_{2} @ \mathrm{CNT}$ (2.596 ̊; CNT denotes the pristine carbon nanotube). The 
induced polarization of the He atoms is more in case of $\mathrm{He}_{2} @ \mathrm{BNCNT}$ as compared to the $\mathrm{He}_{2} @ \mathrm{CNT}$. A similar type of result is also true for the Ng-Ng distances in $\mathrm{Ng}_{n} @ B N C N T(N g=\mathrm{He}(\mathrm{n}=3), \mathrm{Ar}(\mathrm{n}=2)$, $\mathrm{Kr}(\mathrm{n}=2))$. The closed-shell interaction of the He-He and partial covalent characters of Ar-Ar and $\mathrm{Kr}-\mathrm{Kr}$ inside BNCNT cavity are revealed by AIM analysis.

Borospherene $\left(\mathrm{B}_{40}\right)$ can also encapsulate $\mathrm{Ng}$ atoms and systems like $\mathrm{Ng}_{\mathrm{n}} @ \mathrm{~B}_{40}(\mathrm{n}=1$ for He- $\mathrm{Rn}$; $\mathrm{n}=2$ for $\mathrm{He}-\mathrm{Kr}$ ) [140] have been studied using DFT methods. The systems are not thermodynamically stable with respect to the dissociation to $\mathrm{B}_{40}$ cage and free $\mathrm{Ng}$ atoms, but once the entrapped cages are formed, they are kinetically stable due to a high free energy barrier $\left(\Delta G^{\ddagger}\right)$. The $\Delta G^{\ddagger}$ values range from 84.7-206.3 kcal. $\mathrm{mol}^{-1}$ for $\mathrm{Ng} @ \mathrm{~B}_{40}(\mathrm{Ng}=\mathrm{He}-\mathrm{Rn})$ systems. The increase in the size of the $\mathrm{Ng}$ atom increases the distortion in the encapsulated $\mathrm{B}_{40}$ cage in each case. This size effect is enough to explain optimization of $\mathrm{Ng}_{2}$ dimers up to $\mathrm{Kr}$ analogues inside the $\mathrm{B}_{40}$ cage. The Ar-Ar and $\mathrm{Kr}-\mathrm{Kr}$ bonds acquire partially covalent character upon encapsulation. The encapsulation of $\mathrm{Ng}$-atoms changes the fluxional behavior and reactivity of $B_{40}$ cages. $B_{40}$ cage exhibits fluxionality [141-145] which includes a continuous transformation between the $B_{7}$ and $B_{6}$ holes [146]. The $\Delta G^{\ddagger}$ for this transformation increases upon encapsulation of $\mathrm{Ng}$ atom. Furthermore, the presence of $\mathrm{Xe}$ inside the $\mathrm{B}_{40}$ cage enhances the complexation ability of $\mathrm{B}_{40}$ with $\left[\mathrm{Fe}\left(\eta^{5}-\mathrm{C}_{5} \mathrm{Me}_{5}\right)\right]^{+}$as compared to the cage without $\mathrm{Xe}$ atom. Therefore, the above works show that the confined systems may exhibit different and unusual behavior from their free states which has been further highlighted in a recent perspective article [147].

\section{Conclusions}

The present account summarizes our contributions to predicting new $\mathrm{Ng}$ compounds and the bonding therein. We have worked on three different types of $\mathrm{Ng}$ complexes, viz., non-insertion compounds of $\mathrm{NgXY}$ type, insertion compounds of XNgY type and $\mathrm{Ng}$ encapsulated cage complexes, where $X$ and $Y$ represent any atom or group of atoms. Depending on the strength of the interaction, $\mathrm{NgXY}$ might be thermochemically stable at a certain temperature. However, the other two categories are kinetically stable since $\mathrm{XNgY}$ always possesses an exergonic dissociation channel, $\mathrm{XNgY} \rightarrow \mathrm{Ng}+$ $\mathrm{XY}$, and because of the limited space the presence of $\mathrm{Ng}$ causes steric crowding in $\mathrm{Ng}$ encapsulated cage complexes. Therefore, their stability would rely on the activation energy barrier. XNgY molecules are very sensitive to the level of theory. Often a system which is a minimum at DFT level, may dissociate during optimization at the $\operatorname{CCSD}(\mathrm{T})$ level. Therefore, a study at the $\operatorname{CCSD}(\mathrm{T})$ level for this category is highly recommended. For the other types, the bond dissociation energy may vary with the change in the level of theory but such a drastic change in the stability was not found. The bonding analysis is thoroughly scrutinized by employing full theoretical arsenal, viz., NBO, electron density analysis and EDA. Occasionally, they are coupled with AdNDP analysis. In NgXY, the strength of donor-acceptor $\mathrm{Ng} \rightarrow \mathrm{XY}$ interaction depends on the polarizing power of binding $\mathrm{X}$ center to draw the rather rigid electron density of $\mathrm{Ng}$ towards itself, and sometimes involvement of such orbitals becomes large enough, particularly for heavier $\mathrm{Ng}$ elements, to consider them as covalent bonds. On the other hand, in most of the $\mathrm{XNgY}$ cases $\mathrm{Ng}$ forms electron-shared covalent bonds with $\mathrm{X}$ while interacting electrostatically with $\mathrm{Y}$, thus representing itself as $\left[\mathrm{XNg}^{+} \mathrm{Y}^{-}\right.$. Nevertheless, in some of the rare cases like $\mathrm{NCNgNSi}$, both the $\mathrm{C}-\mathrm{Ng}$ and $\mathrm{Ng}-\mathrm{N}$ bonds can be represented as electron-shared covalent bonds. On the other hand, a cage host is an excellent moiety to examine the limits that can be pushed to attain bonding between two $\mathrm{Ng}$ atoms (even for $\mathrm{He}$ ) at high pressure. The confinement effect by a small cage-like $\mathrm{B}_{12} \mathrm{~N}_{12}$ can even induce some covalent interactions between two He atoms in $\mathrm{He}_{2} @ \mathrm{~B}_{12} \mathrm{~N}_{12}$. Starting very lately, the chemistry of noble gases is now at its young age and is developing very rapidly. We believe that $\mathrm{Ng}$ has very widespread hidden chemistry, just waiting to emerge soon!

Author Contributions: R.S. wrote the first version of the full manuscript, revised it thoroughly; G.J. helped in preparation of the manuscript and generated all images; S.P. revised the draft manuscript and suggested positive feedbacks; G.M. and P.K.C. formulated the concept of the manuscript and critically revised the manuscript.

Funding: The work in Mexico was supported by Conacyt (Grant CB-2015-252356). 
Acknowledgments: We would like to thank Professors Luis R. Domingo and Jacky Zhang for kindly inviting us to send an article for the Special Issue of "Molecules" on "The Molecular Electron Density Theory in Organic Chemistry". PKC would like to thank Department of Science and Technology (DST), New Delhi, India for the J. C. Bose National Fellowship, grant number SR/S2/JCB-09/2009. RS and GJ thank UGC, New Delhi, India and IIT Kharagpur, India for their Research Fellowships, respectively. SP thanks Nanjing Tech University for his post doctorate fellowship.

Conflicts of Interest: The authors declare no competing interests.

\section{References}

1. Mendeleev, D. Osnovy Khimii [The Principles of Chemistry]. Ch. 10. 1902, Volume 15, pp. 448-472, S.-Peterburg, M.P. Frolova. Available online: https://www.bookvica.com/pages/books/233/d-i-mendeleev/osnovy-khimiii-e-the-principles-of-chemistry/?soldItem=true (accessed on 11 July 2019).

2. Mewes, J.-M.; Smits, O.R.; Jerabek, P.; Schwerdtfeger, P. Oganesson is a Semiconductor: On the Relativistic Band-Gap Narrowing in the Heaviest Noble-Gas Solids. Angew. Chem. Int. Ed. 2019. [CrossRef] [PubMed]

3. Arny, L.R. The Search for Data in the Physical and Chemical Sciences; Special Libraries Association: Alexandria, VA, USA, 1984.

4. Kossel, W. Über Molekülbildung als Frage des Atombaus. Annalen der Physik 1916, 354, 229-362. [CrossRef]

5. Von Antropoff, A. Die Wertigkeit der Edelgase und ihre Stellung im periodischen System. II. Angew. Chem. Int. Ed. 1924, 37, 695-696. [CrossRef]

6. Laszlo, P.; Schrobilgen, G.J. One or Several Pioneers? The Discovery of Noble-Gas Compounds. Angew. Chem. Int. Ed. 1988, 27, 479-489. [CrossRef]

7. Pauling, L. The formulas of antimonic acid and the antimonates. J. Am. Chem. Soc. 1933, 55, 1895-1900. [CrossRef]

8. Bartlett, N.; Lohmann, D. 1005. Fluorides of the noble metals. Part II. Dioxygenyl hexafluoroplatinate (V), O2+[PtF6]-. J. Am. Chem. Soc. 1962, 5253-5261. [CrossRef]

9. Bartlett, N. Xenon hexafluoroplatinate (V) Xe+[PtF6]-. Proc. Chem. Soc. Lond. 1962, 1962, 218.

10. Hargittai, I. Neil Bartlett and the First Noble-Gas Compound; Springer: Berlin/Heidelberg, Germany, 2009.

11. Graham, L.; Graudejus, O.; Jha, N.K.; Bartlett, N. Concerning the nature of XePtF6. Coord. Chem. Rev. 2000, 197, 321-334. [CrossRef]

12. Craciun, R.; Picone, D.; Long, R.T.; Li, S.; Dixon, D.A.; Peterson, K.A.; Christe, K.O. Third row transition metal hexafluorides, extraordinary oxidizers, and Lewis acids: Electron affinities, fluoride affinities, and heats of formation of $\mathrm{WF}_{6}, \mathrm{ReF}_{6}, \mathrm{OsF}_{6}, \mathrm{IrF}_{6}, \mathrm{PtF}_{6}$, and $\mathrm{AuF}_{6}$. Inorg. Chem. 2010, 49, 1056-1070. [CrossRef]

13. Christe, K.O. Bartlett's discovery of noble gas fluorides, a milestone in chemical history. Chem. Commun. 2013, 49, 4588-4590. [CrossRef]

14. Streng, A.; Kirshenbaum, A.; Streng, L.; Grosse, A. Preparation of Rare-Gas Fluorides and Oxyfluorides by the Electric Discharge Method and their Properties. In Noble Gas Compounds; Hyman, H.H., Ed.; The University of Chicago Press: Chicago, IL, USA, 1963; pp. 73-80.

15. Lehmann, J.F.; Mercier, H.P.; Schrobilgen, G.J. The chemistry of krypton. Coord. Chem. Rev. 2002, $233,1-39$. [CrossRef]

16. Claassen, H.H.; Selig, H.; Malm, J.G. Xenon tetrafluoride. J. Am. Chem. Soc. 1962, 84, 3593. [CrossRef]

17. Slivnik, J.; Brcic, B.; Volavsek, B.; Marsel, J.; Vrscaj, V.; Smalc, A.; Frlec, B.; Zemljic, Z. Über die Synthese von $\mathrm{XeF}_{6}$. Croat. Chem. Acta 1962, 34, 253.

18. Turner, J.; Pimentel, G.C. Krypton fluoride: Preparation by the matrix isolation technique. Science 1963, 140, 974-975. [CrossRef] [PubMed]

19. Nelson, L.Y.; Pimentel, G.C. Infrared detection of xenon dichloride. Inorg. Chem. 1967, 6, 1758-1759. [CrossRef]

20. Bartlett, $\mathrm{N}$; Wechsberg, $\mathrm{M}$. The Xenon Difluoride Complexes $\mathrm{XeF}_{2} \cdot \mathrm{XeOF}_{4} ; \mathrm{XeF}_{2} \cdot \mathrm{XeF}_{6} \cdot \mathrm{AsF}_{5}$ and $\mathrm{XeF}_{2} \cdot 2$ $\mathrm{XeF}_{6} \cdot 2 \mathrm{AsF}_{5}$ and Their Relevance to Bond Polarity and Fluoride Ion Donor Ability of $\mathrm{XeF}_{2}$ and $\mathrm{XeF}_{6} . \mathrm{Z}$. Anorg. Allg. Chem. 1951, 455, 5-17. [CrossRef]

21. Holloway, J.H.; Hope, E.G. Recent advances in noble-gas chemistry. Adv. Inorg. Chem. 1998, 46, 51-100.

22. Stein, L. Ionic radon solutions. Science 1970, 168, 362-364. [CrossRef]

23. Khriachtchev, L.; Pettersson, M.; Runeberg, N.; Lundell, J.; Räsänen, M. A stable argon compound. Nature 2000, 406, 874. [CrossRef] 
24. Frenking, G. Another noble gas conquered. Nature 2000, 406, 836. [CrossRef]

25. Wang, Q.; Wang, X. Infrared Spectra of $\mathrm{NgBeS}(\mathrm{Ng}=\mathrm{Ne}, \mathrm{Ar}, \mathrm{Kr}, \mathrm{Xe})$ and $\mathrm{BeS}_{2}$ in Noble-Gas Matrices. J. Phys. Chem. A 2013, 117, 1508-1513. [CrossRef] [PubMed]

26. Zhang, Q.; Chen, M.; Zhou, M.; Andrada, D.M.; Frenking, G. Experimental and Theoretical Studies of the Infrared Spectra and Bonding Properties of $\mathrm{NgBeCO}_{3}$ and a Comparison with $\mathrm{NgBeO}(\mathrm{Ng}=\mathrm{He}, \mathrm{Ne}, \mathrm{Ar}, \mathrm{Kr}$, Xe). J. Phys. Chem. A 2014, 119, 2543-2552. [CrossRef] [PubMed]

27. Yu, W.; Liu, X.; Xu, B.; Xing, X.; Wang, X. Infrared Spectra of Novel NgBeSO${ }_{2}$ Complexes $(\mathrm{Ng}=\mathrm{Ne}, \mathrm{Ar}, \mathrm{Kr}$, $\mathrm{Xe}$ ) in Low Temperature Matrixes. J. Phys. Chem. A 2016, 120, 8590-8598. [CrossRef] [PubMed]

28. Zhang, Q.; Li, W.L.; Zhao, L.; Chen, M.; Zhou, M.; Li, J.; Frenking, G. A Very Short Be-Be Distance but No Bond: Synthesis and Bonding Analysis of $\mathrm{Ng}_{-} \mathrm{Be}_{2} \mathrm{O}_{2}-\mathrm{Ng}^{\prime}\left(\mathrm{Ng}, \mathrm{Ng}^{\prime}=\mathrm{Ne}, \mathrm{Ar}, \mathrm{Kr}, \mathrm{Xe}\right)$. Chem. Eur. J. 2017, 23, 2035-2039. [CrossRef] [PubMed]

29. Hogness, T.R.; Lunn, E.G. The ionization of hydrogen by electron impact as interpreted by positive ray analysis. Phys. Rev. 1925, 26, 44-55. [CrossRef]

30. Dong, X.; Oganov, A.R.; Goncharov, A.F.; Stavrou, E.; Lobanov, S.; Saleh, G.; Qian, G.-R.; Zhu, Q.; Gatti, C.; Deringer, V.L.; et al. A stable compound of helium and sodium at high pressure. Nat. Chem. 2017, 9, 440-445. [CrossRef]

31. Bellert, D.; Breckenridge, W. Bonding in Ground-State and Excited-State $\mathrm{A}^{+} \cdot \operatorname{Rg}$ van der Waals Ions $(\mathrm{A}=$ Atom, Rg = Rare-Gas Atom): A Model-Potential Analysis. Chem. Rev. 2002, 102, 1595-1622. [CrossRef]

32. Liebman, J.F.; Deakyne, C.A. Noble gas compounds and chemistry: A brief review of interrelations and interactions with fluorine-containing species. J. Fluor. Chem. 2003, 121, 1-8. [CrossRef]

33. Schrobilgen, G.J.; Moran, M.D. Noble-gas compounds. In Kirk-Othmer Encyclopedia of Chemical Technology, 5th ed.; Wiley and Sons, Inc.: New York, NY, USA, 2003.

34. Gerber, R. Formation of novel rare-gas molecules in low-temperature matrices. Annu. Rev. Phys. Chem. 2004, 55, 55-78. [CrossRef]

35. Tavčar, G.; Tramšek, M.; Bunič, T.; Benkič, P.; Žemva, B. New class of coordination compounds with noble gas fluorides as ligands to metal ions. J. Fluor. Chem. 2004, 125, 1579-1584. [CrossRef]

36. Pettersson, M.; Khriachtchev, L.; Lundell, J.; Räsänen, M. Noble gas hydride compounds. In Inorganic Chemistry in Focus II; Meyer, G., Naumann, D., Wesemann, L., Eds.; Wiley-VCH: Weinheim, Germany, 2005; pp. 15-34.

37. Gerber, R. New Chemistry of the Noble Gas Elements: Novel Molecules, Polymers and Clusters. ChemInform 2006, 37, 1-8. [CrossRef]

38. Schrobilgen, G.J.; Gerken, M. Noble gas elements. In The Encyclopedia of Magnetic Resonance, Harris, R.K.; Wasylishen, R.E., Ed.; John Wiley and Sons: New York, NY, USA, 2011.

39. Grochala, W. Atypical compounds of gases, which have been called 'noble'. Chem. Soc. Rev. 2007, 36, 1632-1655. [CrossRef] [PubMed]

40. Khriachtchev, L.; Räsänen, M.; Gerber, R.B. Noble-gas hydrides: New chemistry at low temperatures. Acc. Chem. Res. 2008, 42, 183-191. [CrossRef] [PubMed]

41. Calladine, J.A.; Vuong, K.Q.; Sun, X.Z.; George, M.W. Recent advances in organometallic alkane and noble gas complexes. Pure Appl. Chem. 2009, 81, 1667-1675. [CrossRef]

42. Grandinetti, F. Noble Gas Chemistry: Structure, Bonding, and Gas-Phase Chemistry; John Wiley \& Sons: Hoboken, NJ, USA, 2018.

43. Balta, B.; Gianturco, F.; Paesani, F. Structural properties and quantum effects in protonated helium clusters. II. Quantum Monte Carlo calculations for the smaller aggregates. Chem. Phys. 2000, 254, 215-229. [CrossRef]

44. Ward, T.; Carnegie, P.; Duncan, M. Infrared spectroscopy of the $\mathrm{Ti}\left(\mathrm{H}_{2} \mathrm{O}\right) \mathrm{Ar}^{+}$ion-molecule complex: Electronic state switching induced by argon. Chem. Phys. Lett. 2016, 654, 1-5. [CrossRef]

45. Wagner, J.P.; McDonald, D.C.; Duncan, M.A. An Argon-Oxygen Covalent Bond in the ArOH ${ }^{+}$Molecular Ion. Angew. Chem. Int. Ed. 2018, 57, 5081-5085. [CrossRef]

46. Čurík, R.; Gianturco, F. Indirect dissociative recombination of $\mathrm{LiHe}+$ ions driven by vibrational Feshbach resonances. Phys. Rev. A 2013, 87, 012705. [CrossRef]

47. Rodríguez-Cantano, R.; de Tudela, R.P.; López-Durán, D.; González-Lezana, T.; Gianturco, F.A.; Delgado-Barrio, G.; Villarreal, P. Quantum rotation of $\mathrm{Rb}_{2}\left({ }^{3} \Sigma_{\mathrm{u}}{ }^{+}\right)$attached to HeN droplets: A path-integral Monte Carlo study. Eur. Phys. J. D 2013, 67, 119. [CrossRef] 
48. González-Sánchez, L.; Wester, R.; Gianturco, F. Collisional cooling of internal rotation in MgH+ ions trapped with He atoms: Quantum modeling meets experiments in Coulomb crystals. Phys. Rev. A 2018, 98, 053423. [CrossRef]

49. Zou, W.; Nori-Shargh, D.; Boggs, J.E. On the covalent character of rare gas bonding interactions: A new kind of weak interaction. J. Phys. Chem. A 2012, 117, 207-212. [CrossRef] [PubMed]

50. Schlenker, C.; Dumas, J.; Greenblatt, M.; van Smaalen, S. Physics and Chemistry of Low-Dimensional Inorganic Conductors; Springer Science \& Business Media: Berlin/Heidelberg, Germany, 2012; Volume 354.

51. Grandinetti, F. Gas-phase ion chemistry of the noble gases: Recent advances and future perspectives. Eur. J. Mass Spectrom. 2011, 17, 423-463. [CrossRef] [PubMed]

52. Schrobilgen, G.J.; Brock, D.S. Noble Gases. Annu. Rep. Prog. Chem., Sect. A 2011, 107, 135-141. [CrossRef]

53. Hope, E.G. Coordination chemistry of the noble gases and noble gas fluorides. Coord. Chem. Rev. 2013, 257, 902-909. [CrossRef]

54. Brock, D.S.; Schrobilgen, G.J. Noble-Gas Chemistry. In Comprehensive Inorganic Chemistry II; Reedijk, J., Poepplemeier, K., Eds.; Elsevier: Amsterdam, The Netherlands, 2013; Volume 1, pp. 755-822.

55. Haner, J.; Schrobilgen, G.J. The chemistry of Xenon (IV). Chem. Rev. 2015, 115, 1255-1295. [CrossRef] [PubMed]

56. Lai, T.-Y.; Yang, C.-Y.; Lin, H.-J.; Yang, C.-Y.; Hu, W.-P. Benchmark of density functional theory methods on the prediction of bond energies and bond distances of noble-gas containing molecules. J. Chem. Phys. 2011, 134, 244110. [CrossRef] [PubMed]

57. Glendening, E.D.; Landis, C.R.; Weinhold, F. NBO 6.0: Natural bond orbital analysis program. J. Comput. Chem. 2013, 34, 1429-1437. [CrossRef]

58. Bader, R.F. Atoms in molecules. Acc. Chem. Res. 1985, 18, 9-15. [CrossRef]

59. Michalak, A.; Mitoraj, M.; Ziegler, T. Bond orbitals from chemical valence theory. J. Phys. Chem. A 2008, 112, 1933-1939. [CrossRef]

60. Mitoraj, M.P.; Michalak, A.; Ziegler, T. A combined charge and energy decomposition scheme for bond analysis. J. Chem. Theory. Comput. 2009, 5, 962-975. [CrossRef]

61. Saha, R.; Pan, S.; Merino, G.; Chattaraj, P.K. Unprecedented Bonding Situation in Viable $\mathrm{E}_{2}\left(\mathrm{NHB}^{\mathrm{Me}}\right)_{2}(\mathrm{E}=\mathrm{Be}$, $\left.\mathrm{Mg} ; \mathrm{NHB}^{\mathrm{Me}}=\left(\mathrm{HCN}^{\mathrm{Me}}\right)_{2} \mathrm{~B}\right)$ Complexes: Neutral $\mathrm{E}_{2}$ Forms a Single E-E Covalent Bond. Angew. Chem. Int. Ed. 2019, 58, 8372-8377. [CrossRef] [PubMed]

62. Saha, R.; Pan, S.; Chattaraj, P.K. Stabilization of Boron-Boron Triple Bonds by Mesoionic Carbenes. ACS Omega 2018, 3, 13720-13730. [CrossRef]

63. Saha, R.; Pan, S.; Frenking, G.; Chattaraj, P.K.; Merino, G. The Strongest CO Binding and the Largest C-O Stretching Frequency. Phys. Chem. Chem. Phys. 2017, 19, 2286-2293. [CrossRef] [PubMed]

64. Pan, S.; Saha, R.; Osorio, E.; Chattaraj, P.K.; Frenking, G.; Merino, G. Ligand Supported E 3 Clusters (E = Si Sn). Chem. Eur. J. 2017, 23, 7463-7473. [CrossRef] [PubMed]

65. Barroso, J.; Cabellos, J.L.; Pan, S.; Murillo, F.; Zarate, X.; Fernandez-Herrera, M.A.; Merino, G. Revisiting the Racemization Mechanism of Helicenes. Chem. Commun. 2018, 54, 188-191. [CrossRef] [PubMed]

66. Pecher, L.; Pan, S.; Frenking, G. Chemical bonding in the hexamethylbenzene-SO ${ }^{2+}$ dication. Theor. Chem. Acc. 2019, 138, 47. [CrossRef]

67. Jin, J.; Pan, S.; Jin, X.; Lei, S.; Zhao, L.; Frenking, G.; Zhou, M. Octacarbonyl Anion Complexes of the Late Lanthanides $\operatorname{Ln}(\mathrm{CO})_{8}{ }^{-}(\mathrm{Ln}=\mathrm{Tm}, \mathrm{Yb}, \mathrm{Lu})$ and the 32-Electron Rule. Chem. Eur. J. 2019, 25, 3229-3234. [CrossRef] [PubMed]

68. Chi, C.; Pan, S.; Meng, L.; Luo, M.; Zhao, L.; Zhou, M.; Frenking, G. Alkali Metal Covalent Bonding in Nickel Carbonyl Complexes ENi(CO) ${ }_{3}{ }^{-}$. Angew. Chem. Int. Ed. 2019, 58, 1732-1738. [CrossRef]

69. Su, W.; Pan, S.; Sun, X.; Wang, S.; Zhao, L.; Frenking, G.; Zhu, C. Double dative bond between divalent carbon(0) and uranium. Nat. Commun. 2018, 9, 4997. [CrossRef]

70. Wu, X.; Zhao, L.; Jin, J.; Pan, S.; Li, W.; Jin, X.; Wang, G.; Zhou, M.; Frenking, G. Observation of alkaline earth complexes $\mathrm{M}(\mathrm{CO})_{8}(\mathrm{M}=\mathrm{Ca}$, Sr, or Ba) that mimic transition metals. Science 2018, 361, 912-916. [CrossRef]

71. Zhao, L.; Pan, S.; Holzmann, N.; Schwerdtfeger, P.; Frenking, G. Chemical Bonding and Bonding Models of Main-Group Compounds. Chem. Rev. 2019, 119, 8781-8845. [CrossRef] [PubMed]

72. Pauzat, F.; Ellinger, $\mathrm{Y}_{\mathrm{H}_{3}}{ }^{+}$as a trap for noble gases: 1-The case of Argon. Planet. Space Sci. 2005, 53, 1389-1399. [CrossRef] 
73. Pauzat, F.; Ellinger, $\mathrm{Y} . \mathrm{H}_{3}{ }^{+}$as a trap for noble gases-2: structure and energetics of $\mathrm{XH}_{3}{ }^{+}$complexes from $\mathrm{X}=$ neon to xenon. J. Chem. Phys. 2007, 127, 014308. [CrossRef] [PubMed]

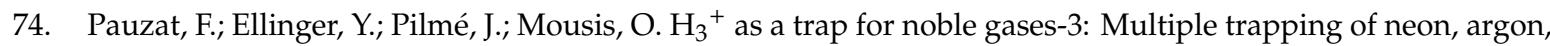
and krypton in $\mathrm{X}_{\mathrm{n}} \mathrm{H}_{3}{ }^{+}(\mathrm{n}=1-3)$. J. Chem. Phys. 2009, 130, 174313. [CrossRef] [PubMed]

75. Chakraborty, A.; Giri, S.; Chattaraj, P.K. Trapping of noble gases (He-Kr) by the aromatic $\mathrm{H}_{3}{ }^{+}$and $\mathrm{Li}_{3}{ }^{+}$ species: a conceptual DFT approach. New J. Chem. 2010, 34, 1936-1945. [CrossRef]

76. Jana, G.; Pan, S.; Rodríguez-Kessler, P.L.; Merino, G.; Chattaraj, P.K. Adsorption of Molecular Hydrogen on Lithium-Phosphorus Double-Helices. J. Phys. Chem. C 2018, 122, 27941-27946. [CrossRef]

77. Pan, S.; Giri, S.; Chattaraj, P.K. A Computational study on the hydrogen adsorption capacity of various lithium-doped boron hydrides. J. Comp. Chem. 2012, 33, 425-434. [CrossRef]

78. Pan, S.; Banerjee, S.; Chattaraj, P.K. Role of Lithium Decoration on Hydrogen Storage. J. Mex. Chem. Soc. 2012, 56, 229-240. [CrossRef]

79. Pan, S.; Merino, G.; Chattaraj, P.K. Hydrogen Trapping Potential of Some Li-doped Star-like Clusters and Super-alkali Systems. Phys. Chem. Chem. Phys. 2012, 14, 10345-10350. [CrossRef]

80. Saha, R.; Pan, S.; Chattaraj, P.K. Hydrogen storage in all-metal and non-metal aromatic clusters. In Emerging Materials for Energy Conversion and Storage; Cheong, K.Y., Impellizzeri, G., Fraga, M.A., Eds.; Elsevier: Amsterdam, The Netherlands, 2018; pp. 329-362.

81. Perez-Peralta, N.; Contreras, M.; Tiznado, W.; Stewart, J.; Donald, K.J.; Merino, G. Stabilizing carbon-lithium stars. Phys. Chem. Chem. Phys. 2011, 13, 12975-12980. [CrossRef]

82. Tong, J.; Li, Y.; Wu, D.; Li, Z.-R.; Huang, X.-R. Ab Initio Investigation on a New Class of Binuclear Superalkali Cations $\mathrm{M}_{2} \mathrm{Li}_{2 \mathrm{k}+1}{ }^{+}\left(\mathrm{F}_{2} \mathrm{Li}_{3}{ }^{+}, \mathrm{O}_{2} \mathrm{Li}_{5}{ }^{+}, \mathrm{N}_{2} \mathrm{Li}_{7}{ }^{+}\right.$, and $\left.\mathrm{C}_{2} \mathrm{Li}_{9}{ }^{+}\right)$. J. Phys. Chem. A 2011, 115, 2041-2046. [CrossRef] [PubMed]

83. Pan, S.; Contreras, M.; Romero, J.; Reyes, A.; Chattaraj, P.K.; Merino, G. $\mathrm{C}_{5} \mathrm{Li}_{7}{ }^{+}$and $\mathrm{O}_{2} \mathrm{Li}_{5}{ }^{+}$as Noble-Gas-Trapping Agents. Chem. Eur. J. 2013, 19, 2322-2329. [CrossRef] [PubMed]

84. Pan, S.; Jalife, S.; Romero, J.; Reyes, A.; Merino, G.; Chattaraj, P.K. Attractive Xe-Li Interaction in Li-Decorated Clusters. Comput. Theor. Chem. 2013, 1021, 62-69. [CrossRef]

85. Pan, S.; Saha, R.; Gupta, A.; Chattaraj, P.K. Modeling of 1-D Nanowires and analyzing their Hydrogen and Noble Gas Binding Ability. J. Chem. Sci. 2017, 129, 849-858. [CrossRef]

86. Frenking, G.; Koch, W.; Gauss, J.; Cremer, D. Stabilities and nature of the attractive interactions in HeBeO, $\mathrm{NeBeO}$, and $\mathrm{ArBeO}$ and a comparison with analogs $\mathrm{NgLiF}, \mathrm{NgBN}$, and $\mathrm{NgLiH}(\mathrm{Ng}=\mathrm{He}$, Ar). A theoretical investigation. J. Am. Chem. Soc. 1988, 110, 8007-8016. [CrossRef]

87. Thompson, C.A.; Andrews, L. Noble gas complexes with BeO: infrared spectra of NG-BeO (NG = Ar, Kr, $\mathrm{Xe}$ ). J. Am. Chem. Soc. 1994, 116, 423-424. [CrossRef]

88. Linguerri, R.; Komiha, N.; Hochlaf, M. Solvation effects and stabilization of multicharged ions: a case study of $\mathrm{Ar}_{\mathrm{m}} \mathrm{BeO}^{+}$complexes. Phys. Chem. Chem. Phys. 2012, 14, 4236-4243. [CrossRef]

89. Pan, S.; Jalife, S.; Kumar, R.M.; Subramanian, V.; Merino, G.; Chattaraj, P.K. Structure and Stability of $(\mathrm{NG})_{\mathrm{n}} \mathrm{CN}_{3} \mathrm{Be}_{3}{ }^{+}$Clusters and Comparison with (NG)BeY ${ }^{0 /+}$. Chem. Phys. Chem. 2013, 14, 2511-2517. [CrossRef]

90. Pan, S.; Moreno, D.; Cabellos, J.L.; Merino, G.; Chattaraj, P.K. Ab initio study on the stability of $\mathrm{NgnBe}_{2} \mathrm{~N}_{2}$, $\mathrm{Ng}_{n} \mathrm{Be}_{3} \mathrm{~N}_{2}$ and $\mathrm{NgBeSiN}_{2}$ Clusters. Chem. Phys. Chem. 2014, 15, 2618-2625. [CrossRef]

91. Borocci, S.; Bronzolino, N.; Grandinetti, F. From OBeHe to $\mathrm{H}_{3} \mathrm{BOBeHe}$ : Enhancing the stability of a neutral helium compound. Chem. Phys. Lett. 2005, 406, 179-183. [CrossRef]

92. Pan, S.; Moreno, D.; Cabellos, J.L.; Romero, J.; Reyes, A.; Merino, G.; Chattaraj, P.K. In quest of strong Be-Ng bonds among the neutral Ng-Be complexes. J. Phys. Chem. A 2013, 118, 487-494. [CrossRef] [PubMed]

93. Saha, R.; Pan, S.; Merino, G.; Chattaraj, P.K. Comparative Study on the Noble-Gas Binding Ability of BeX Clusters (X= $\left.\mathrm{SO}_{4}, \mathrm{CO}_{3}, \mathrm{O}\right)$. J. Phys. Chem. A 2015, 119, 6746-6752. [CrossRef] [PubMed]

94. Pan, S.; Ghara, M.; Ghosh, S.; Chattaraj, P.K. Noble gas bound beryllium chromate and beryllium hydrogen phosphate: a comparison with noble gas bound beryllium oxide. RSC Adv. 2016, 6, 92786-92794. [CrossRef]

95. Pan, S.; Saha, R.; Chattaraj, P.K. On the stability of noble gas bound 1-tris (pyrazolyl) borate beryllium and magnesium complexes. New J. Chem. 2015, 39, 6778-6786. [CrossRef]

96. Saha, R.; Pan, S.; Chattaraj, P.K. NgMCp ${ }^{+}$: Noble Gas Bound Half-Sandwich Complexes (Ng= He-Rn, $\mathrm{M}=$ $\mathrm{Be}-\mathrm{Ba}$, and $\mathrm{Cp}=\eta^{5}-\mathrm{C}_{5} \mathrm{H}_{5}$ ). J. Phys. Chem. A 2017, 121, 3526-3539. [CrossRef] [PubMed] 


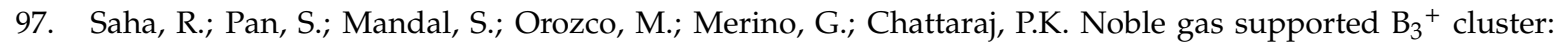
formation of strong covalent noble gas-boron bonds. RSC Adv. 2016, 6, 78611-78620. [CrossRef]

98. Li, Z.Z.; Li, A.Y. ( $\mathrm{Rg}=\mathrm{He} \sim \mathrm{Rn}, \mathrm{n}=1-4)$ : In quest of the potential trapping ability of the aromatic ring. Int. J. Quantum Chem. 2018, 118, e25530. [CrossRef]

99. Li, Z.Z.; Li, A.Y. Monocyclic aromatic compounds $\mathrm{B}_{\mathrm{n}} \operatorname{Rg}_{\mathrm{n}}{ }^{(\mathrm{n}-2)+}$ of boron and rare gases. Phys. Chem. Chem. Phys. 2017, 19, 19109-19119. [CrossRef]

100. Huang, Y.H.; Li, Z.Z.; Li, A.Y. Hexagonal boron-noble gas compounds $\mathrm{B}_{6} \mathrm{Ng}_{\mathrm{n}}{ }^{4+}$ : Structures and bonding. Chem. Phys. Lett. 2017, 689, 82-91. [CrossRef]

101. Pan, S.; Moreno, D.; Merino, G.; Chattaraj, P.K. Stability of Noble-Gas-Bound $\mathrm{SiH}_{3}{ }^{+}$Clusters. Chem. Phys. Chem. 2014, 15, 3554-3564. [CrossRef]

102. Pan, S.; Moreno, D.; Ghosh, S.; Chattaraj, P.K.; Merino, G. Structure and stability of noble gas bound compounds $(\mathrm{E}=\mathrm{C}, \mathrm{Ge}, \mathrm{Sn}, \mathrm{Pb} ; \mathrm{X}=\mathrm{H}, \mathrm{F}, \mathrm{Cl}, \mathrm{Br})$. J. Comput. Chem. 2016, 37, 226-236. [CrossRef] [PubMed]

103. Ghara, M.; Pan, S.; Kumar, A.; Merino, G.; Chattaraj, P.K. Structure, Stability, and Nature of Bonding in Carbon Monoxide bound $\mathrm{EX}_{3}{ }^{+}$Complexes ( $\mathrm{E}=$ Group 14 element; $\left.\mathrm{X}=\mathrm{H}, \mathrm{F}, \mathrm{Cl}, \mathrm{Br}, \mathrm{I}\right)$. J. Comp. Chem. 2016, 37, 2202-2211. [CrossRef] [PubMed]

104. Chakraborty, D.; Chattaraj, P.K. In quest of a superhalogen supported covalent bond involving a noble gas atom. J. Phys. Chem. A 2015, 119, 3064-3074. [CrossRef] [PubMed]

105. Pan, S.; Saha, R.; Mandal, S.; Chattaraj, P.K. $\sigma$-Aromatic cyclic $\mathrm{M}_{3}{ }^{+}(\mathrm{M}=\mathrm{Cu}, \mathrm{Ag}, \mathrm{Au})$ clusters and their complexation with dimethyl imidazol-2-ylidene, pyridine, isoxazole, furan, noble gases and carbon monoxide. Phys. Chem. Chem. Phys. 2016, 18, 11661-11676. [CrossRef] [PubMed]

106. Ghara, M.; Pan, S.; Deb, J.; Kumar, A.; Sarkar, U.; Chattaraj, P.K. A computational study on structure, stability and bonding in Noble Gas bound metal Nitrates, Sulfates and Carbonates (Metal = Cu, Ag, Au). J. Chem. Sci. 2016, 128, 1537-1548. [CrossRef]

107. Pan, S.; Gupta, A.; Saha, R.; Merino, G.; Chattaraj, P.K. A coupled-cluster study on the noble gas binding ability of metal cyanides versus metal halides (metal $=\mathrm{Cu}, \mathrm{Ag}, \mathrm{Au}$ ). J. Comput. Chem. 2015, 36, 2168-2176. [CrossRef]

108. Pan, S.; Saha, R.; Kumar, A.; Gupta, A.; Merino, G.; Chattaraj, P.K. A noble interaction: An assessment of noble gas binding ability of metal oxides (metal $=\mathrm{Cu}, \mathrm{Ag}$, Au). Int. J. Quantum Chem. 2016, 116, 1016-1024. [CrossRef]

109. Jana, G.; Pan, S.; Chattaraj, P.K. Binding of Small Gas Molecules by Metal-Bipyridyl Monocationic Complexes (Metal $=\mathrm{Cu}, \mathrm{Ag}, \mathrm{Au})$ and Possible Bond Activations Therein. J. Phys. Chem. A 2017, 121, 3803-3817. [CrossRef] [PubMed]

110. Jana, G.; Saha, R.; Pan, S.; Kumar, A.; Merino, G.; Chattaraj, P.K. Noble Gas Binding Ability of Metal-Bipyridine Monocationic Complexes $($ Metal = Cu, Ag, Au): A Computational Study. ChemistrySelect 2016, 1, 5842-5849. [CrossRef]

111. Pan, S.; Jana, G.; Merino, G.; Chattaraj, P.K. Noble-Noble Strong Union: Gold at Its Best to Make a Bond with a Noble Gas Atom. ChemistryOpen 2019, 8, 173-187. [CrossRef]

112. Li, T.-H.; Liu, Y.-L.; Lin, R.-J.; Yeh, T.-Y.; Hu, W.-P. On the stability of noble gas molecules. Chem. Phys. Lett. 2007, 434, 38-41. [CrossRef]

113. Perez-Peralta, N.; Juarez, R.; Cerpa, E.; Bickelhaupt, F.M.; Merino, G. Bonding of Xenon Hydrides. J. Phys. Chem. A 2009, 113, 9700-9706. [CrossRef] [PubMed]

114. Juarez, R.; Zavala-Oseguera, C.; Jimenez-Halla, J.O.C.; Bickelhaupt, F.M.; Merino, G. Radon hydrides: structure and bonding. Phys. Chem. Chem. Phys. 2011, 13, 2222-2227. [CrossRef] [PubMed]

115. Pan, S.; Saha, R.; Chattaraj, P. Exploring the nature of silicon-noble gas bonds in $\mathrm{H}_{3} \mathrm{SiNgNSi}$ and $\mathrm{HSiNgNSi}$ compounds (Ng = Xe, Rn). Int. J. Mol. Sci. 2015, 16, 6402-6418. [CrossRef] [PubMed]

116. Pan, S.; Gupta, A.; Mandal, S.; Moreno, D.; Merino, G.; Chattaraj, P.K. Metastable behavior of noble gas inserted tin and lead fluorides. Phys. Chem. Chem. Phys. 2015, 17, 972-982. [CrossRef] [PubMed]

117. Samanta, D. Prediction of superhalogen-stabilized noble gas compounds. J. Phys. Chem. Lett. 2014, 5, 3151-3156. [CrossRef]

118. Saha, R.; Mandal, B.; Chattaraj, P.K. $\mathrm{HNgBeF}_{3}(\mathrm{Ng}=\mathrm{Ar}-\mathrm{Rn})$ : Superhalogen-supported noble gas insertion compounds. Int. J. Quantum Chem. 2018, 118, e25499. [CrossRef] 
119. Pan, S.; Jana, G.; Ravell, E.; Zarate, X.; Osorio, E.; Merino, G.; Chattaraj, P.K. Stable NCNgNSi (Ng=Kr, Xe, $\mathrm{Rn})$ Compounds with Covalently Bound C-Ng-N Unit: Possible Isomerization of NCNSi through the Release of the Noble Gas Atom. Chem. Eur. J. 2018, 24, 2879-2887. [CrossRef]

120. Mondal, S.; Cabellos, J.L.; Pan, S.; Osorio, E.; Torres-Vega, J.J.; Tiznado, W.; Restrepo, A.; Merino, G. $10-\pi$-Electron arenes à la carte: structure and bonding of the $\left[\mathrm{E}-\left(\mathrm{C}_{\mathrm{n}} \mathrm{H}_{\mathrm{n}}\right)-\mathrm{E}\right]^{\mathrm{n}-6}(\mathrm{E}=\mathrm{Ca}, \mathrm{Sr}, \mathrm{Ba} ; \mathrm{n}=6-8)$ complexes. Phys. Chem. Chem. Phys. 2016, 18, 11909-11918. [CrossRef]

121. Wang, Q.; Pan, S.; Lei, S.; Jin, J.; Deng, G.; Wang, G.; Zhao, L.; Zhou, M.; Frenking, G. Octa-coordinated alkaline earth metal-dinitrogen complexes $\mathrm{M}\left(\mathrm{N}_{2}\right)_{8}(\mathrm{M}=\mathrm{Ca}, \mathrm{Sr}, \mathrm{Ba})$. Nat. Commun. 2019, 10, 3375. [CrossRef]

122. Jana, G.; Pan, S.; Merino, G.; Chattaraj, P.K. Noble Gas Inserted Metal Acetylides (Metal= Cu, Ag, Au). J. Phys. Chem. A 2018, 122, 7391-7401. [CrossRef] [PubMed]

123. Jana, G.; Pan, S.; Merino, G.; Chattaraj, P.K. $\mathrm{MNgCCH}(\mathrm{M}=\mathrm{Cu}, \mathrm{Ag}, \mathrm{Au} ; \mathrm{Ng}=\mathrm{Xe}, \mathrm{Rn})$ : The First Set of Compounds with M-Ng-C Bonding Motif. J. Phys. Chem. A 2017, 121, 6491-6499. [CrossRef] [PubMed]

124. Jana, G.; Pan, S.; Osorio, E.; Zhao, L.; Merino, G.; Chattaraj, P.K. Cyanide-isocyanide isomerization: stability and bonding in noble gas inserted metal cyanides (metal $=\mathrm{Cu}, \mathrm{Ag}, \mathrm{Au}$ ). Phys. Chem. Chem. Phys. 2018, 20, 18491-18502. [CrossRef] [PubMed]

125. Yoshizawa, M.; Tamura, M.; Fujita, M. Diels-Alder in Aqueous Molecular Hosts: Unusual regioselectivity and Efficient Catalysis. Science 2006, 312, 251-254.

126. Krapp, A.; Frenking, G. Is this a chemical bond? a theoretical study of $\mathrm{Ng}_{2} @ \mathrm{C}_{60}(\mathrm{Ng}=\mathrm{He}, \mathrm{Ne}, \mathrm{Ar}, \mathrm{Kr}, \mathrm{Xe})$. Chem. Eur. J. 2007, 13, 8256-8270. [CrossRef] [PubMed]

127. Khatua, M.; Pan, S.; Chattaraj, P.K. Movement of $\mathrm{Ng}_{2}$ molecules confined in a $\mathrm{C}_{60}$ cage: an ab initio molecular dynamics study. Chem. Phys. Lett. 2014, 610, 351-356. [CrossRef]

128. Kroto, H.W. The Stability of the Fullerenes $C_{n}$, with $n=24,28,32,25,36,50,60$ and 70. Nature 1987, 329, 529-531. [CrossRef]

129. Jalife, S.; Mondal, S.; Cabellos, J.L.; Pan, S.; Méndez-Rojas, M.A.; Fernández, I.; Frenking, G.; Merino, G. Breaking the isolated pentagon rule by encapsulating $\mathrm{Xe}_{2}$ in $\mathrm{C}_{60}$ : The guest defines the shape of the host. ChemistrySelect 2016, 1, 2405-2408. [CrossRef]

130. Cerpa, E.; Krapp, A.; Flores-Moreno, R.; Donald, K.J.; Merino, G. Influence of endohedral confinement on the electronic interaction between He atoms: $\mathrm{A} \mathrm{He}_{2} @ \mathrm{C}_{20} \mathrm{H}_{20}$ case study. Chem. Eur. J. 2009, 15, 1985-1990. [CrossRef]

131. Cerpa, E.; Krapp, A.; Vela, A.; Merino, G. The implications of symmetry of the external potential on bond paths. Chem. Eur. J. 2008, 14, 10232-10234. [CrossRef]

132. Khatua, M.; Pan, S.; Chattaraj, P.K. Confinement induced binding of noble gas atoms. J. Chem. Phys. 2014, 140, 164306. [CrossRef]

133. Mondal, S.; Chattaraj, P.K. Noble gas encapsulation: clathrate hydrates and their HF doped analogues. Phys. Chem. Chem. Phys. 2014, 16, 17943-17954. [CrossRef] [PubMed]

134. Pan, S.; Jana, G.; Gupta, A.; Merino, G.; Chattaraj, P.K. Endohedral Gas Adsorption by Cucurbit[7]uril: A Theoretical Study. Phys. Chem. Chem. Phys 2017, 19, 24448-24452. [CrossRef] [PubMed]

135. Pan, S.; Saha, R.; Mandal, S.; Mondal, S.; Gupta, A.; Fernández, H.M.; Merino, G.; Chattaraj, P.K. Selectivity in Gas Adsorption by Molecular Cucurbit[6]uril. J. Phys. Chem. C 2016, 120, 13911-13921. [CrossRef]

136. Pan, S.; Mondal, S.; Chattaraj, P.K. Cucurbiturils as Promising Hydrogen Storage Materials: A Case Study of Cucurbit[7]uril. New J. Chem. 2013, 37, 2492-2499. [CrossRef]

137. Pan, S.; Mandal, S.; Chattaraj, P.K. Cucurbit [6] uril: a possible host for noble gas atoms. J. Phys. Chem. B 2015, 119, 10962-10974. [CrossRef] [PubMed]

138. Chakraborty, D.; Pan, S.; Chattaraj, P.K. Encapsulation of small gas molecules and rare gas atoms inside the octa acid cavitand. Theor. Chem. Acc. 2016, 135, 119. [CrossRef]

139. Chakraborty, D.; Chattaraj, P.K. Confinement induced binding in noble gas atoms within a BN-doped carbon nanotube. Chem. Phys. Lett. 2015, 621, 29-34. [CrossRef]

140. Pan, S.; Ghara, M.; Kar, S.; Zarate, X.; Merino, G.; Chattaraj, P.K. Noble gas encapsulated $B_{40}$ cage. Phys. Chem. Chem. Phys. 2018, 20, 1953-1963. [CrossRef]

141. Hua-Jin, Z.; Jin-Chang, G.; Lin-Yan, F.; Ying-Jin, W.; Jalife, S.; Vásquez-Espinal, A.; Cabellos, J.L.; Pan, S.; Merino, G. Triple Coaxial- layered versus helical $\mathrm{Be}_{6} \mathrm{~B}_{11}{ }^{-}$cluster: dual structural fluxionality and multifold aromaticity. Angew. Chem. Int. Ed. 2017, 129, 10308-10311. 
142. Saha, R.; Kar, S.; Pan, S.; Martínez-Guajardo, G.; Merino, G.; Chattaraj, P.K. A spinning umbrella: carbon monoxide and dinitrogen bound $\mathrm{MB}_{12}{ }^{-}$clusters $(\mathrm{M}=\mathrm{Co}, \mathrm{Rh}, \mathrm{Ir})$. J. Phys. Chem. A 2017, 121, 2971-2979. [CrossRef]

143. Jalife, S.; Liu, L.; Pan, S.; Cabellos, J.L.; Osorio, E.; Lu, C.; Heine, T.; Donald, K.J.; Merino, G. Dynamical behavior of boron clusters. Nanoscale 2016, 8, 17639-17644. [CrossRef] [PubMed]

144. Liu, L.; Moreno, D.; Osorio, E.; Castro, A.C.; Pan, S.; Chattaraj, P.K.; Heine, T.; Merino, G. Structure and bonding of $\mathrm{IrB}_{12}{ }^{-}$: Converting a rigid boron $\mathrm{B}_{12}$ platelet to a Wankel motor. RSC Adv. 2016, 6, 27177-27182. [CrossRef]

145. Moreno, D.; Pan, S.; Martínez-Guajardo, G.; Lei-Zeonjuk, L.; Islas, R.; Osorio, E.; Chattaraj, P.K.; Heine, T.; Merino, G. $\mathrm{B}_{18}{ }^{2-}$ : A quasi-planar bowl member of the Wankel motor family. Chem. Commun. 2014, 50, 8140-8143. [CrossRef] [PubMed]

146. Martinez-Guajardo, G.; Cabellos, J.L.; Diaz-Celaya, A.; Pan, S.; Islas, R.; Chattaraj, P.K.; Heine, T.; Merino, G. Dynamical behavior of borospherene: A nanobubble. Sci. Rep. 2015, 5, 11287. [CrossRef] [PubMed]

147. Chakraborty, D.; Chattaraj, P.K. Bonding, Reactivity and Dynamics in Confined Systems. J. Phys. Chem. A 2019, 123, 4513-4531. [CrossRef]

(C) 2019 by the authors. Licensee MDPI, Basel, Switzerland. This article is an open access article distributed under the terms and conditions of the Creative Commons Attribution (CC BY) license (http://creativecommons.org/licenses/by/4.0/). 